\title{
CONSTRUINDO UMA OUTRA SOCIEDADE: OCAPITAL SOCIAL NA ESTRUTURAÇÃO DE UMA CULTURA POLIITICA PARTICIPATIVA NO BRASIL
}

\author{
Marcello Baquero
}

\begin{abstract}
RESUMO
Este artigo examina a relação entre democracia, cultura política e capital social no Brasil. O tema é abordado de maneira compreensiva, pois acredita-se que esses conceitos interagem permanentemente. No caso brasileiro é possivel, entretanto, identificar alguns fatores que historicamente têm incidido na configuração de um tipo de cultura política, de caráter híbrido, que mistura posturas favoráveis à democracia e predisposições negativas em relação às instituições políticas. Esse mal-estar, argumenta-se, não é conjuntural nem temporário, mas de caráter estrutural e danoso para o fortalecimento democrático. Em tal cenário o desenvolvimento do capital social, aumentaria, prática e teoricamente, o poder dos cidadãos permitindo-lhes maior inserção e participação na arena política. São utilizados como fonte dados de pesquisas qualitativas e quantitativas coletados no Rio Grande do Sul no período de 1974 a 2000. Os resultados do estudo sugerem uma ausência de capacidade cooperativa entre os brasileiros, o que poderia explicar os déficits de participação politica e a conseqüente instabilidade democrática.
\end{abstract}

PALAVRAS-CHAVE: cultura política; democracia; capital social; participação política.

\section{INTRODUÇÃO}

Os esforços empreendidos no Brasil para fortalecer sua democracia, desde o início do processo de redemocratização, têm convergido para a defesa de maior participação da cidadania nos processos de decisão política e na fiscalização dos gestores públicos. Tais esforços têm visado reverter o crescente processo de desintegração social, resultado, entre outros fatores, da diminuição do Estado como fruto da adoção de uma perspectiva neoliberal que desestruturou a sociedade sem gerar uma contrapartida criativa que possibilitasse articular um espaço comum sob novas regras. Segundo Lechner (1990), o que está claro na América Latina - e que se considera aplicável também ao Brasil - é o fracasso da tentativa de instituir a coordenação social baseada na racionalidade do mercado, conquanto esta não se sustenta por si só nem sustenta uma ordem e uma orientação comunitária que favoreçam a integração social.

Tal situação estimulou a realização de estudos e pesquisas de caráter multidisciplinar que passaram a refletir sobre a importância de redescobrir e recuperar o Estado e a sociedade, valorizando, sobretudo, a participação cidadã. Como sugere Sen (1998, p. 597), "a relevância intrínseca dos direitos civis e políticos [acrescenta-se: os direitos huma- nos, também] garantidos pela democracia, autoriza a defender sua vigência sem que seja necessário demonstrar se essa forma de democracia fomenta ou não o crescimento econômico. Esse posicionamento não deixa de ser uma novidade se considerando que por muito tempo a teoria democrática liberal vigente recomendou sacrificar alguns direitos políticos e civis, por os considerar como obstáculos para o desenvolvimento".

Assim, o reconhecimento e valorização de fatores "subjetivos" na democracia têm levado atores sociais e políticos a um consenso, cada vez maior, sobre a necessidade de evitar a fragmentação da sociedade e, em decorrência, evitar o questionamento da validade do sistema democrático. Os desafios imediatos relacionados a essa problemática dizem respeito a como estimular e motivar os cidadãos a participar politicamente em um contexto de fragmentação e crescente desigualdade social? Como criar e/ou reconstituir um ambiente estimulante para a participação política? Tais desafios são gigantescos, pois o Estado, ao longo de sua história, tem perdido a credibilidade em convocar seus cidadãos para enfrentar essa tarefa. Tornouse imperativo, portanto, refletir sobre mecanismos que proporcionem o retorno do cidadão à esfera política. 
A despeito disso, deve-se salientar que se tem modificado, substancialmente, o pensamento ortodoxo sobre a participação cidadã, que a limitava a ações convencionais. Atualmente, verifica-se uma reorientação teórico-prática significativa no país, que reabilita, não só na retórica, mas também na prática, a noção de sociedade em que as pessoas deveriam ter mais poder e ingerência na fiscalização dos gestores públicos. Em tal cenário, quais são as ramificações dessa reorientação tanto na dimensão dos gestores públicos como na dimensão da sociedade civil? A tensão da relação entre Estado e sociedade que caracteriza o Brasil está atenuando-se por esse movimento? É possível afirmar que há um revigoramento do papel do cidadão na esfera pública? Existe capital social? E, se existe, contribui para melhorar a qualidade da democracia?

$\mathrm{Na}$ tentativa de responder a essas indagações tem-se verificado uma produção substancial de estudos e pesquisas dedicada à temática de revalorização da participação política dos cidadãos. No entanto, parece que, apesar do reconhecimento do papel do indivíduo no processo político, poucos esforços têm sido empreendidos para materializar esse papel na realidade cotidiana. Constatam-se lacunas e deficiências na compreensão sobre quais mecanismos funcionam (ou não) na dinâmica de capacitar os cidadãos para uma maior e mais qualificada participação na política. Uma dessas lacunas refere-se ao papel do capital social e sua influência (ou sua ausência) na estruturação de uma sociedade mais democrática que precisa ser examinado. Dessa forma, este artigo busca compreender como se dá o processo de desenvolvimento de interesses políticos em um contexto caracterizado pela desigualdade social e crescente pobreza e analisa as possibilidades de constituir capital social como fator de empowerment dos setores excluídos. Isso deve ser entendido como um instrumento complementar e não como substituto de mecanismos convencionais de ingerência política, capaz de agregar os cidadãos na busca de objetivos comuns e não em um sentido de isolamento corporativo. Trata-se, portanto, de sugerir caminhos que proporcionem a visibilidade e resolução das demandas desses setores públicos que historicamente estiveram à margem da preocupação dos governantes, junto com aqueles grupos que gozam de privilégios, em virtude de sua capacidade associativa e corporativa. Essencialmente, pretende-se responder à seguinte pergunta: é possível dar poder ("to empower") aos cidadãos individualmente, aumentando sua capacidade colaborativa em contextos caracterizados por práticas políticas tradicionais, por padrões de desigualdade social e em ambiente de desconfiança generalizada? E, se afirmativo, esse processo contribui para a melhoria da qualidade da democracia no país? Para responder a essas perguntas utilizam-se dados de pesquisas qualitativas e quantitativas realizadas no Rio Grande do Sul ${ }^{1}$.

\section{O CIDADÃO NA POLÍTICA}

Pensar em mecanismos que proporcionem uma democracia social mais justa implica trazer as pessoas para a esfera pública. Tal transição depende, fundamentalmente, da capacidade do Estado e de suas instituições de aceitar e valorizar essa participação. Uma democracia social sem políticos ou cidadãos democráticos está fadada ao fracasso.

Nessa linha de análise, para alguns autores (KRISHNA, 2002, p. 437), a mera existência de instituições democráticas criadas de cima para baixo não é suficiente para garantir a estabilidade política, e, menos ainda, a justiça social. A menos que os cidadãos tenham fé nessas instituições e envolvam-se em atividades de auto-governança, a democracia enquanto conceito e enquanto prática pode tornar-se algo destituído de significado, usado para legitimar práticas autoritárias e de corrupção institucionalizada, pois a cidadania social não se faz presente. Segundo Iazzetta (2000, p. 40), "si la ausencia de ciudadanía social nos conmueve,

\footnotetext{
1 Apesar da existência de bancos de dados sobre a cultura política na América Latina (Latinobarómetro, World Values Survey, Encuesta Panamericana, Cesop), ainda se verificam problemas de continuidade e de padronização de perguntas. As questões formuladas nem sempre correspondem às definições que alguns autores dão aos mesmos conceitos. Assim, prender-se a esses dados poderia limitar algumas reflexões teóricas que vão além dessas dimensões, quando se incorporam indicadores pontuais de atitudes e comportamentos. Como nosso objetivo é de natureza compreensiva, optou-se por utilizar várias fontes regionais para tentar responder às questões formuladas neste artigo. Acredita-se que as inferências que se fazem a partir desses dados encontram respaldo na teoria e, fundamentalmente, na história de grande parte dos países da região latinoamericana. Pesquisas qualitativas e quantitativas levadas a cabo em cidades do Rio Grande do Sul, tanto com adolescentes quanto com eleitores adultos, são utilizadas para apreender como se dá o processo de constituição de normas, valores e crenças a respeito da dimensão política, bem como se esses elementos contribuem (ou não) para a constituição de capital social.
} 
no es solo porque ofende a la dignidad humana sino porque socava las posibilidades de aquellos de actuar autónomamente en su relación con otros ciudadanos y con el Estado e, continua, el verdadero desafío reside por consiguiente en construir una sociedad más justa y hacerlo democráticamente".

Historicamente, a ausência de uma maior participação das pessoas no Brasil tem mostrado que a democracia de procedimentos não tem conseguido legitimar-se por seus próprios valores, pois, presentemente, o grau de contestação é alto e a participação das pessoas em atividades convencionais (pertencer a partidos, participar de comícios, discutir política, entre outros) é reduzida. O dilema enfrentado pelo país é de que os recursos econômicos para satisfazer as demandas materiais básicas são insuficientes, levando a um processo acelerado de desagregação da vida social. A história recente tem mostrado que sociedades nessas condições dificilmente promovem o estabelecimento de culturas políticas participativas - ao contrário, caracterizam-se pela ineficiência, corrupção ou regimes despóticos.

Dessa forma, a crise da democracia formal seu sistema histórico-social acumula contradições que não se podem resolver por meio de ajustes dentro dos padrões institucionais vigentes - pode ser identificada como resultado de quatro fatores (HIRST, 2002, p. 412-414): a) um declínio da participação política com evidência de uma crescente alienação da política e insatisfação com os políticos; b) a perda da capacidade de governança, por parte dos estados, em virtude tanto do processo de globalização quanto da mudança da esfera pública para o mercado. Particularmente, as políticas neoliberais têm estimulado a instalação de uma moldura legal que favorece e garante a livre circulação de bens e capitais que possibilitaram, com sucesso, a retirada crescente do Estado das áreas sociais com a privatização dos serviços públicos, beneficiando as empresas transnacionais. A forma como tem aparecido a contradição entre a racionalidade do mercado e a racionalidade local tem sido em termos do crescente desemprego, de uma exclusão social maciça, da expansão da pobreza, da supressão de garantias públicas para a terceira idade e para a juventude, da redução de gastos nas áreas sociais, da desmobilização social e na descrença em projetos emancipatórios. Nesse contexto de crise, o grande desafio é como resgatar a dignidade humana (MARGULIS, 1996, p. 8).
Geralmente os efeitos da globalização tem sido e é utilizada por governantes para implementar políticas públicas, consideradas inevitáveis, mas que resultam no agravamento do quadro social; c) as bases sociais da participação democrática e o pluralismo político em culturas caracterizadas por associações fortes estão ameaçadas por seu perceptível declínio, como também da participação não política (social). Os cidadãos começam a relacionar-se com o mundo muito mais via meios de comunicação eletrônicos, passando mais tempo isolados uns dos outros e em um consumo privado. Em países como o Brasil, essa fase convive paralelamente com uma crescente exclusão social; d) é fato que a amplitude tanto da democracia formal quanto das associações voluntárias é mais uma característica das sociedades avançadas, por serem elas sociedades organizacionais. Tal cenário afasta a sociedade civil como ente de controle e fiscalização tanto das instituições estatais quanto das organizações privadas. Dessa forma, os cidadãos perdem poder tanto como empregados quanto como consumidores. Assim, a democracia organizacional não promove valores democráticos de consulta sobre os interesses das pessoas afetadas por suas decisões. Outrossim, este tipo de democracia encoraja o controle hierárquico, gerando, a passividade por parte dos controlados. Embora essas condições não sejam propícias à solidez democrática, esses países têm conseguido manter uma certa estabilidade política longitudinal, em virtude das políticas públicas que incidem positivamente na qualidade de vida dos seus cidadãos. O problema surge quando esses elementos aparecem em sociedades como a brasileira, em que a dimensão material essencial (saúde, moradia, emprego) está longe de ser resolvida.

No caso do Brasil, constata-se uma contradição entre um avanço tecnológico acelerado simultaneamente com o agravamento do quadro social, o que tem levado a que quanto mais aumente a exclusão social e o contingente de excluídos, menor é a capacidade do Estado em responder às demandas desses grupos. $\mathrm{O}$ resultado tem sido o de que as pessoas têm começado a inventar e encontrar mecanismos informais de transmitir suas demandas sociais e, cada vez mais, tentam resolver essas reivindicações sem a ingerência do Estado. Constata-se, assim, o desenvolvimento crescente de novas formas de mobilização cultural e formas alternativas de construção de identidades e participação coletivas no contexto da precariedade do 
Estado, necessárias para a sobrevivência dos excluídos, em condiçõos de carência, privação e desigualdade $^{2}$.

As perspectivas para o futuro nessas circunstâncias não são promissoras, se examinado o legado histórico que privilegiava caminhos e soluções meramente técnicos. Por exemplo, nas décadas de 1980 e 1990 a nação brasileira enfrentou gravíssimos problemas sociais e econômicos que influenciaram decisivamente a produção acadêmica, que até então privilegiava soluções técnicas e institucionais, colocando o cidadão apenas como espectador ou em um papel não-protagônico. A crise econômica e o crescimento da pobreza e da exclusão social catalisaram o interesse, por parte da comunidade acadêmica e de organismos nacionais e internacionais, pelas redes sociais como elementos geradores de soluções. Institucionalizou-se um interesse sobre o tipo de capital social que seria relevante para as camadas tradicionalmente excluídas das políticas sociais e passou-se a reconhecer e aceitar a idéia de que a democracia requer, pelo menos, um nível mínimo de capital social, ou seja, normas e formas de associação que possibilitariam o surgimento de confiança dos cidadãos nas autoridades constituídas e nas instituições vigentes.

Essas reflexões levaram ao questionamento da modernização do capitalismo, pois seu pressuposto de que somente a tecnologia pode trazer vantagens para o desenvolvimento social mostrou-se falso. Prova disso é que a maior parte do mundo tem seguido esse modelo e o problema social não tem sido resolvido. As tentativas de explicar o fracasso das instituições políticas como geradoras únicas e eficientes de legitimidade vão desde os teóricos da modernização, que atribuem o atraso político aos baixos níveis de alfabetização, urbanização e desenvolvimento industrial, até, em uma outra perspectiva, os teóricos do desenvolvimento, tais como Huntington (1975), que considerava a instabilidade política como resultado de uma participação crescente e descontrolada, em virtude da capacidade limitada de respostas por parte do Estado, bem como de um desenvolvimento institucional inadequado. Por sua vez, os teóricos da dependência argumentavam que a estrutura econômica internacional e nacional produzia entre

2 Esse fenômeno é conhecido como "resiliência", isto é, a capacidade de as pessoas adaptarem-se positivamente à sociedade, em condições adversas (MELILLO \& OJEDA, 2001). os países da América Latina e os outros países desenvolvidos forças inimigas ao desenvolvimento democrático. Por sua vez, a perspectiva de cultura política tentava explicar como o legado cultural ibérico gerou valores deletérios para o amadurecimento democrático.

Nesta última perspectiva, atribuiu-se uma relevância especial à coesão da família e da comunidade como elemento tangível na possibilidade de um desenvolvimento econômico eficiente, em áreas em que o Estado tem fracassado. Para alguns autores (HIRST, 2002, p. 409), esses elementos propiciaram o surgimento da chamada democracia associativa; esse tipo de democracia - ao contrário da doutrina econômica liberal, que tenta limitar as funções do Estado e privilegia o mercado como regulador das relações sociais - busca a expansão da governança democrática e da sociedade civil. A ênfase que se coloca no associativismo procura responder à crise da eficiência declinante da democracia por procedimentos e o crescente descontentamento dos cidadãos com um Estado centralizador e padronizado nas suas ações; ao mesmo tempo, propicia elementos de fiscalização para os cidadãos (accountability). Busca-se, por esse caminho, democratizar o Estado e a sociedade ao mesmo tempo em que os fortalece.

É importante ressaltar que as dificuldades das abordagens alternativas em fortalecerem-se resulta, também, da tenacidade com que o mundo acadêmico aderiu às linhas estabelecidas de análise, negligenciando, nesse processo, o exame do novo ou não-antecipado. Um desses fenômenos diz respeito a formas alternativas de participação e mobilização política à margem das instituições convencionais e socialmente aceitas. No entanto, a bibliografia até recentemente teimou em negar seu significado ou têm-nas colocado em segundo plano em relação às análises de engenharia institucional. A consequiência tem sido a prevalência de um conhecimento reativo que parece estar sempre começando do zero. Parece que estamos sempre reagindo às teorizações que vêm de fora, ao invés de refletir, de maneira autóctone, utilizando o diálogo com o conhecimento estabelecido como contra-argumento à construção de explicações teóricas alternativas.

\section{A REINVENÇÃO DA CIDADANIA}

A materialização do cidadão no processo político tem sido constatado particularmente no contexto do fortalecimento de entidades locais, 
organizações não-governamentais (ONGs), associações de moradores e organizações voluntárias, entre outras. No campo do reativamento do poder local, por exemplo, várias experiências têm mostrado que a guinada para o seu revigoramento tem possibilitado uma ingerência maior dos cidadãos na política (FACHIN \& CHARLAT, 1998). De fato, tem-se argumentado que as políticas para o desenvolvimento local são mais eficientes quando formuladas e implementadas por uma cooperação próxima entre os atores públicos e privados (COUTO, 1995; SOARES, 1996; COOKE \& MORGAN, 1998; MOURA, 1998; SOARES \& PONTES, 1998; PEREIRA, 1999).

Uma das razões desse movimento da reativação do local pode ser atribuído ao desencanto das pessoas com os programas sociais do governo, principalmente em relação à pobreza, ao desemprego e à decadência comunitária. A consequiência tem sido a busca das organizações engendradas informalmente na sociedade, por parte dos cidadãos, como alternativas preferenciais na resolução dos problemas, evidenciando o distanciamento do cidadão das instituições políticas convencionais da democracia formal como seus interlocutores efetivos.

As organizações alternativas às tradicionais (partidos) são vistas crescentemente como sendo mais flexíveis e efetivas do que os programas patrocinados pelo Estado. Também são consideradas mais capazes de estruturar suas atividades às necessidades e circunstâncias comunitárias. Assim, em virtude das deficiências da democracia representativa, um número crescente de pessoas parece depositar fé na ação da sociedade civil no processo de regeneração política. A esse respeito Smuloviz e Peruzzotti (2000), propõem o conceito de "accountability societal" como complementar ao de "accountability horizontal" que ocorre dentro do Estado, como mecanismo que possibilita o controle e a fiscalização dos gestores públicos, por meio de recursos não institucionais e cuja efetividade está baseada em sanções simbólicas.

Esse movimento é relativamente recente, pois o enfoque predominante na Ciência Política era, e é, institucionalista e de procedimentos ou a chamada democracia minimalista. Por muito tempo, tornou-se consensual que regimes democráticos são mais bem definidos em termos de procedimentos e não em termos de substância. Emblemático desse posicionamento é o estudo de Ros- tow (1970) sobre transições democráticas, em que afirmava peremptoriamente que "há um reconhecimento geral de que a democracia é essencialmente um assunto de procedimento e não de substância" (idem, p. 421). Na mesma linha de análise Diamond (1996, p. 3) afirma que "felizmente, a maioria das definições sobre democracia atualmente (em contraste com as das décadas de 1960 e 1970) convergem para definir a democracia como um sistema de autoridade política, separada de qualquer elemento econômico e social". Essas perspectivas sobre democracia têm sido questionadas, particularmente no que diz respeito à América Latina, onde, por exemplo, segundo Camp (2001, p. 9), "o que mais distingue a versão latino-americana de democracia daquela dos Estados Unidos é a ênfase na igualdade econômica e social e no progresso".

Parte significativa da produção contemporânea sobre democracia na América Latina rejeita afirmações de caráter minimalista por as considerar pouco úteis na reflexão dos dilemas desses países, bem como por terem sido derrubadas pelos fatos contemporâneos. A história encarregou-se de mostrar as limitações desses argumentos, pois as democracias, nessa região, continuam a evidenciar sérios problemas sociais, portanto de substância, o que obrigou uma reavaliação das referidas perspectivas teóricas, redirecionando a discussão no sentido de resgatar o cidadão para a esfera política. Atualmente está claro que as pessoas que não têm poder (empowerment) submetem-se facilmente a discursos populistas ou simplesmente caem em uma passividade permanente. Tais elementos são danosos para a democracia. Esse fenômeno não é monopólio dos países em desenvolvimento, mas também começa a ser observado nas economias centrais. Por exemplo, para alguns autores (KARL, BANDUCCI \& BOWLER, 2003), o declínio do engajamento cívico na União Européia é um sintoma do descontentamento da população e uma crise de legitimidade.

Tal situação tem-se estendido de maneira negativa para os países da América Latina, onde se verifica o precário grau de legitimidade que os governos latino-americanos têm experimentado nos últimos anos e que se tem materializado em ações que não respeitam os direitos humanos de todos os cidadãos, bem como em uma crescente indiferença dos governantes pelos problemas dos países. Esse processo, que para alguns autores caracteriza a desinstitucionalização do Estado 
(GARAY, 2001), tem levado a uma perda da noção do bem comum e à prevalência de interesses particulares, fragilizando, dessa maneira, a convivência cidadã e acarretando uma vulnerabilidade do contrato social. Constata-se nesse cenário uma aculturação (formação prática de princípios e fundamentos que regem comportamentos dos cidadãos) de atitudes e comportamentos que desvalorizam as práticas democráticas e levam a uma erosão de princípios básicos de convivência pacífica. Tal situação tem levado a que "la enraizada fragmentación del tejido social, la deslegitimación del Estado y la perdida de convivencia ciudadana se manifiestan no sólo en el deterioro de comportamiento y conductas ciudadanas sino en las relaciones políticas, económicas, sociales y culturales, al hacerlas proclives a la configuración de lo que se puede denominar como un proceso de 'aculturación de la ilegalidad' y en ciertos campos, hasta una 'aculturación mafiosa' a cargo de grupos poderosos que van superditando y condicionando paulatinamente actitudes e inclusive algunos valores de otros grupos y estratos de la sociedad. Lo que, entre otras cosas, va afectando la misma cultura cívica o la civilidad en amplios sectores de la sociedad" (idem, p. 3).

Cabe ressaltar que tal comportamento é o resultado não de uma predisposição dos cidadãos em privilegiar a informalidade, a apatia ou a alienação, mas da atual desordem política, econômica, social e cultural que caracteriza a sociedade contemporânea. O'Donnell (1994) tem chamado as democracias latino-americanas com essas características de "democracias delegativas". $\mathrm{Na}$ "democracia representativa", os governantes eleitos representam os eleitores, enquanto na "democracia delegativa" os governantes, uma vez eleitos, fazem prevalecer sua vontade particular em detrimento da comunidade em um sentido amplo. Tais elementos também contribuem para o surgimento do que Parga (2001) denomina de processo de corrupção da democracia, o qual não será resolvido com mais leis, mais regras ou mais procedimentos democráticos formais. Nessa linha de análise, Touraine (1997) argumenta que alguns atores e observadores consideram a volta de processos eleitorais livres como uma comprovação da vitória da democracia. Segundo ele, essa conclusão não pode ser aceita como verdadeira. A decadência das idéias e dos movimentos revolucionários e contra-revolucionários pode significar um retrocesso da política desvinculada da maior parte da sociedade, o que é positivo, porém não indica, de per se, a criação ou o fortalecimento da democracia. Naturalmente esses argumentos não implicam sugerir que instituições não sejam consideradas importantes ou colocá-las em segundo plano - tal posicionamento seria ingênuo. Trata-se, sim, de incorporar explicações alternativas aos déficits democráticos observados no país, indo além da engenharia institucional. A esse respeito Lechner (1994) defende que a menos que se desenvolva uma racionalidade normativa, vale dizer, uma cultura política que valorize a democracia como valor, junto a uma racionalidade técnico-instrumental, o processo de modernização democrática somente poderá assentar-se em bases autoritárias de dominação. Deve-se reconhecer, entretanto, que o processo de reorientação teórica é lento e insatisfatório. Os chamados modelos alternativos são ainda frágeis e dependem de respaldo empírico.

A ênfase nas instituições foi necessário, e inevitável, em uma determinada época, particularmente durante a redemocratização do país, pois uma das primeiras etapas era a reconstituição das instituições políticas. Tal tarefa era imperativa no estágio inicial da construção democrática; a institucionalização dessas organizações, entretanto, nos anos posteriores, não implicou a resolução dos problemas de estabilidade e fortalecimento democrático. A história mostra que, mesmo com instituições políticas poliárquicas, o país não conseguiu reverter seus padrões tradicionais de autoritarismo e práticas populistas. Tal comportamento redundou no distanciamento deliberado dos governantes em relação aos problemas mais urgentes, levando ao seu isolamento e à reincidência de práticas autoritárias no trato da coisa pública. Evidenciou, portanto, a impossibilidade desses governos em utilizar as instituições vigentes para realizar mediações efetivas de relações sociais autônomas. Dessa forma, a democracia contemporânea no país temse tornado excessivamente padronizada, em que o respeito às instituições limita-se a uma função legitimadora das autoridades políticas. Segundo Valdés, "é necessário superar o mito que reduz a democracia ao processo técnico, sem examinar seu verdadeiro conteúdo, que é o resultado da soma de valores éticos e culturais historicamente determinados" (VALDÉS, 2002, p. 36). É por essa razão que se tornou imperativo buscar outras explicações e soluções para esses problemas.

A revalorização da política da sociedade civil e, conseqüentemente, do papel atribuído ao 
cidadão como sujeito integrante das políticas públicas não se restringe à dimensão institucionalformal, segundo a qual os procedimentos poliárquicos servem como fatores de empowerment das pessoas, principalmente por meio das eleições como principal fator de controle popular dos representantes eleitos. A esse respeito Joslyn e Ligler (2001) argumentam que, embora as eleições ofereçam aos cidadãos um mecanismo institucional para expressar seu ponto de vista pró ou contra o governo, implicitamente proporcionam os meios para afirmar a crença na legitimidade do sistema político vigente. A história recente do Brasil, entretanto, tem mostrado que esse procedimento poliárquico, sem negar sua importância, não se tem constituído no fator de poder do cidadão. Pelo contrário, a despeito da existência de eleições, segundo dados de pesquisas eleitorais levadas a cabo na América Latina nos últimos quinze anos (BAQUERO, 2001), os eleitores parecem mais desconfiados e mais decepcionados com a política - a conseqüência parece ter sido a institucionalização de uma apatia generalizada em relação aos meios convencionais da política (partidos, eleições e procedimentos formais, de maneira geral).

Em relação a isso, Young (2000, p. 4) afirma que chegamos a um momento histórico paradoxal, em que quase todos parecem ser favoráveis à democracia, mas poucos acreditam que um governo democrático possa fazer alguma coisa. Os processos democráticos, em muitos casos, parecem paralisar o processo de tomada de decisões. Atualmente é vista com ceticismo a noção de que com boas instituições e com boas intenções e predisposições das pessoas para engajarem-se politicamente garante-se a estabilidade democrática.

Ao mesmo tempo em que a perspectiva institucional é questionada, várias e distintas formas alternativas de participação política, que não encontram explicações teóricas adequadas no conhecimento estabelecido, têm surgido. Por exemplo, o movimento de Chiapas no México, o movimento indígena no Equador, o Movimento dos Trabalhadores Rurais Sem Terra no Brasil, além das milhares de iniciativas documentadas em relação a grupos da sociedade que se organizam espontaneamente em prol de objetivos comuns (Revista do Terceiro Setor, 2003). A ausência de marcos explicativos sobre esses movimentos, possibilitaram discussões sobre o papel das associações voluntárias e/ou informais como entidades geradoras de reflexões e práticas de inclusão cidadã. Assim, as associações cívicas e voluntárias são crescentemente vistas como sendo importantes no resgate do cidadão para a esfera pública e na promoção da discussão política e das políticas do governo. De modo geral, essas organizações, por meio da estruturação e dedicação à margem de um apoio institucional, em muitos casos têm conseguido mobilizar os cidadãos marginalizados socialmente para pressionar o Estado a responder às suas demandas.

Nesse sentido, uma segunda dimensão de valorização do cidadão tem emergido recentemente, relacionando-se à possibilidade de empowerment dos cidadãos por meio do capital social, o qual se refere ao envolvimento dos indivíduos em atividades coletivas que geram benefícios em um espectro mais amplo. Essa guinada para explicações alternativas de empowerment e participação política têm gerado uma produção científica significativa sobre a validade ou não do paradigma de capital social no processo de fortalecimento da democracia contemporânea. Um corolário resultante é que quando há, de fato, um processo interativo para decidir sobre assuntos comunitários, o lado "perdedor" não questiona a legitimidade do resultado, pois a decisão passou por uma discussão pública, inclusiva e regular do ponto de vista de procedimentos. Uma das consequiências desse debate tem sido a proliferação de estudos que tem orientado sua preocupação para avaliar a qualidade da democracia nos países em desenvolvimento (BAKER, 1999; BAQUERO, 2003).

Estudos iniciais cuja preocupação era encontrar mecanismos de ampliação da democracia em um sentido maximalista defendiam o processo de descentralização, pois, por meio desse instrumento, as relações entre o Estado, o mercado e a sociedade civil seriam mais eficientes. Segundo Guallida e Perez (2002), a democracia fundamentada nos princípios da descentralização transcende a definição que particulariza a dimensão processual caracterizada pela existência de eleições livres, liberdade de associação, accountability e o controle civil da instituição militar como é defendido pela abordagem institucionalista.

Outrossim, a democracia resultante de um processo de descentralização transcende a democracia representativa, pois implica que o processo de tomadas de decisões resulte da negociação estabelecida diretamente entre os vários atores sóciopolíticos que influenciam a agenda política (GUA- 
DILLA \& PEREZ, 2002, p. 90). Outrossim, um dos objetivos da descentralização é a eliminação de procedimentos clientelísticos na relação Estadosociedade. O problema, entretanto, é o pressuposto da descentralização que visualiza o cidadão comum como um ator social com poder e capaz de fazer prevalecer seu ponto de vista, em um contexto de deliberação, o que está longe da realidade, pois, de maneira geral, a maior parte da população não vê nos mecanismos de deliberação, por não estar preparada, uma saída para seus problemas.

Assim, ampliar a participação dos cidadãos na política tem a ver com a forma como eles descodificam e internalizam normas e valores em relação à política, ou seja, o tipo de cultura política. Em uma avaliação retrospectiva sobre a importância da cultura política na explicação dos fenômenos políticos e sociais, constata-se que ela era vista como algo secundário, negligenciando uma discussão mais aprofundada sobre seu papel na configuração de um sistema democrático e participativo.

\section{O RESSURGIMENTO DA CULTURA POLÍ- TICA}

A retomada de estudos sobre cultura política pode ser atribuída ao colapso do marxismo e ao ressurgimento do nacionalismo, por um lado, e às deficiências explicativas das abordagens institucionais, por outro, estimulando o interesse sobre como os regimes políticos legitimam-se e como os cidadãos posicionam-se frente a esses elementos. Nas últimas duas décadas tem-se institucionalizado o axioma de que os regimes democráticos dependem, para sua sobrevivência, do apoio dos cidadãos bem como de sua confiança nas instituições e nos governantes. Isso se aplica, sobretudo, aos regimes que estão no processo de amadurecer e estabilizar suas democracias. Embora não seja possível estabelecer o grau de apoio necessário para fortalecer a estabilidade política, o consenso é de que, sem ele, os regimes políticos serão ineficientes e com pouca credibilidade, mesmo tendo sido eleitos pelo voto popular e funcionando dentro dos marcos poliárquicos da legalidade.

A premissa que vincula o apoio político à estabilidade democrática remonta aos clássicos, porém sua materialização empírica teve início com David Easton (1965), que diferenciou apoio especifico (às instituições e aos governantes), que é o resultado de um quid pro quo pela satisfação do atendimento às demandas da população, de apoio difuso, que significa uma lealdade generalizada não contingenciada pelas recompensas de curto prazo. O importante a ressaltar é que essas duas dimensões estão organicamente ligadas e que a estabilidade democrática depende de ambas.

A importância atribuída à cultura política e à sociedade civil está presente em quase todos os clássicos da democracia (Tocqueville, Rousseau, Aristóteles, Platão) e nas mais recentes reflexões sobre a importância de trazer de volta o cidadão para a esfera política (Habermas, Pateman, Mouffe, Giddens, Touraine). Do ponto de vista dessas perspectivas alternativas, a cultura é vista como dinâmica e não estática e que evolui constantemente sob a influência de fatores externos e internos. Sua base, no entanto, constitui-se de fatores duradouros que a tornam diferente de outras culturas. Tal síntese materializa-se em crenças, predisposições, motivações e normas de fazer as coisas de um povo. No entanto, junto com valores positivos são construídos valores que influenciam a forma como as pessoas fazem e vêem as coisas em um determinado contexto.

Assim, mesmo que conceitos como atraso, miséria, fome, clientelismo, personalismo, patrimonialismo não possam ser considerados como valores culturais, eles são assimilados pela cultura e naturalizados, gerando, no campo da política, uma cultura passiva, silenciosa e pouco participativa. É o que se denomina de fatores históricoestruturais (BAQUERO \& PRA, 1995).

Esses fatores historicamente possibilitaram a subordinação política dos cidadãos a determinados candidatos em troca de favores do Estado que, em princípio e segundo o marco jurídico, deveriam estar disponíveis para todos. Não é, entretanto, o que ocorre. Via de regra, o comum é que o político aproprie-se de recursos públicos (patrimonialismo) para conseguir a subordinação política, pois desse mecanismo depende sua reeleição - mas os que se subordinam obtêm, de maneira privilegiada, o que deveriam ser bens de acesso público. Dessa forma, o clientelismo funciona como um espelho, pois ao particularismo dos políticos corresponde o particularismo dos eleitores. Em tal cenário o tipo de cultura política que surge permite que o assistencialismo atue como um mecanismo poderoso de cooptação e controle dos cidadãos. O paradoxal da situação é que essa prática funciona em virtude das deficiências e 
incapacidade do Estado em responder às demandas da população.

Foram essas preocupações que fizeram que ressurgisse o interesse sobre a cultura política pois a constatação da crise da democracia representativa, com sua ênfase no mercado e na racionalidade dos atores como enfoque predominante, não consegue explicar o crescente descontentamento dos cidadãos com as instituições políticas e sociais.

Tal situação estimulou na Ciência Política um redirecionamento para pesquisas de cultura política, que assumem posicionamento ontológico claro de que a cultura é fundamental na compreensão dos fenômenos políticos. Não se trata da defesa de posicionamento monolítico sobre a supremacia da abordagem da cultura política vis-à-vis outras perspectivas teóricas, mas de uma abordagem compreensiva que incorpora as explicações institucionais. A esse respeito, Inglehart (1988, p. 1223) argumenta que está, cada vez mais, evidente a precariedade dos modelos que ignoram os aspectos culturais.

O primeiro passo na direção de valorizar a cultura política surgiu no trabalho de Almond e Verba (1965), em uma perspectiva comparativa empírica sobre a cultura política de cinco países. Apesar das criticas feitas a esse trabalho (estático, normativo, voluntarista) - muitas delas plenamente justificáveis - uma contribuição importante e que prevalece ao longo do tempo diz respeito à importância atribuída, pelos autores, a normas e valores culturais como fundamentais na persistência da democracia de massa. Na perspectiva da cultura política são as atitudes e as expectativas em relação ao sistema político que mantêm a comunidade nacional integrada. Os valores e atitudes são avaliados em termos de como agem no sentido da manutenção da comunidade em um sentido nacional. Nessa perspectiva, quando se observam polarizações de atitudes a consequiência é a desordem e a instabilidade. Visto dessa forma, a teoria da cultura política centra-se na problemática da estabilidade. Os autores da cultura cívica preocupamse com o estabelecimento das condições sob as quais as democracias são estáveis e detêm uma autoridade legítima. Outrossim, do ponto de vista da teoria da cultura política, Estado e sociedade são entidades separadas que são integradas por meio de instituições intermediárias (formais e informais) via processo de socialização política. As pes- quisas de opinião são fundamentais para avaliar como os cidadãos internalizam crenças em relação a essas instituições e deduz-se dessas crenças o grau de legitimidade do sistema político. No caso do Brasil, várias pesquisas têm sido levadas a cabo nessa direção (LAMOUNIER \& SOUZA, 1991; MOISÉS, 1995; BAQUERO, 2001). Tais pesquisas constataram que o legado histórico tem uma influência fundamental na compreensão das razões que levaram ao surgimento e manutenção de uma cultura política fragmentada e silenciosa no Brasil. Como consequiência, estabeleceu-se a importância de reconhecer as singularidades de sua cultura com vistas a buscar respostas eficientes aos seus problemas.

Segundo a teoria da cultura política, a confiança interpessoal e a confiança nas instituições políticas são pré-condições para a formação de associações secundárias que, por sua vez, podem agir como promotoras da participação política e, conseqüentemente, no aperfeiçoamento da democracia. Para o bom funcionamento das instituições políticas é imperativa a confiança dos cidadãos nelas. Se em um sentido causal não se pode especificar o que antecede o quê, do ponto de vista mais compreensivo essa relação é inegável. $\mathrm{O}$ desafio está em encontrar mecanismos que possibilitem uma integração entre esses conceitos de modo a conferir poder aos cidadãos para uma ingerência maior na política. A esse respeito Przeworski (1999) tem argumentado que os defensores do capitalismo concluem equivocadamente que a maneira ótima de gerar resultados econômicos seria reduzir a função econômica do governo, quando o que é necessário é garantir que a conduta do governo seja submetida a uma fiscalização atenta por parte dos cidadãos. Em síntese, a economia melhora quando melhora a qualidade da democracia, garantindo aos cidadãos que possam exigir do governo responsabilidades pela condução econômica e social do país.

A capacidade de fiscalização, entretanto, passa por um processo de capacitação (educação política) das pessoas para não só se interessarem nos assuntos de natureza política, como também, fundamentalmente, participarem dessa arena. Alcançar esse objetivo, entretanto, é tarefa gigantesca se avaliados os indicadores de escolaridade no país. Em pesquisa divulgada pela Organização das Nações Unidas para a Educação, a Ciência e a Cultura (UNESCO) em julho de 2003 (ABRAMOVAY \& CASTRO, 2003), constatou-se que cerca de 
$50 \%$ dos alunos brasileiros na faixa dos 15 anos, estão abaixo ou no chamado nível 1 de alfabetização, marca estabelecida pela UNESCO que classifica os alunos que conseguem apenas lidar com tarefas muito básicas de leitura. Ao mesmo tempo, em uma escala sobre níveis de compreensão de leitura englobando 41 países, o Brasil está quase no fim da fila: $37^{\mathrm{a}}$ posição - à frente (e não muito) na América Latina somente do Peru (Revista do Terceiro Setor, 2003). O que está claro, atualmente, é que educação para a democracia não existe. Como constituir cidadãos críticos e orientados para uma participação política maior em tal cenário? Esse parece um dos principais desafios que os cientistas políticos têm que responder, pois o que se verifica na prática é uma situação de apatia e um senso de impotência para resolver as coisas. Esse tipo de comportamento parece um fenômeno global. Por exemplo, segundo alguns autores (PUTNAM \& GOSS, 2002) existe atualmente um processo generalizado de "desengajamento cívico". No caso brasileiro, tal erosão dos laços sociais manifesta-se em uma cultura da lealdade que raramente vai além da família e do grupo de amigos mais próximos. O setor público é visto com desconfiança e a noção de bem comum é frágil. Mas o que mais surpreende é a aparente indiferença das pessoas em relação a essas práticas. O resultado concreto é a ausência de políticas de inclusão social e uma tendência a desestimular a participação dos cidadãos.

Nesse cenário, deparamo-nos com um regime democrático convivendo com um Estado oligárquico. O regime promove o respeito à Constituição, às leis, às instituições e aos procedimentos democráticos. No entanto, é controlado por poderes patrimonialistas de grupos minoritários que agem em detrimento do bem coletivo, promovendo, dessa forma, uma concentração maior de riquezas de setores privilegiados, acentuando a desigualdade e a exclusão social. Para tentar reverter esse processo, Putnam e Gross (idem), baseados em teorias desenvolvidas há mais de um século e, em nossa opinião, de aplicação universal, têm proposto que os graves problemas econômicos, políticos e sociais de um sistema político não podem ser resolvidos pela mera existência de instituições, mas é necessário fortalecer as redes de solidariedade entre os cidadãos. Nessa mesma linha de pensamento, Young argumenta que "até as supostamente sociedades mais democráticas do mundo na maior parte do tempo são democracias 'plebiscitárias': os candidatos posicionam-se vagamente sobre os assuntos políticos, os cidadãos apóiam-se uns aos outros e têm pouca relação com o processo político, até a próxima eleição" (YOUNG, 2000, p. 5) e acrescenta que "o espírito e a prática democráticos inspiram muitas organizações voluntárias; movimentos compostos de tais grupos algumas vezes influenciam as ações do governo e as ações de outras instituições poderosas" (ibidem).

Segundo Putnam, o conceito que enfoca a importância da promoção e do fortalecimento da solidariedade - capital social - não é novo, pois tem sido reinventado pelo menos seis vezes desde que apareceu nos trabalhos de Hanifan (1916). Em tempos recentes o conceito de capital social tem sido utilizado de maneira multidisciplinar, levando a um consenso de que a evidência gerada por esses estudos permite afirmar que as características da sociedade civil afetam a saúde da democracia, das comunidades e das pessoas (PUTNAM \& GOSS, 2002).

Tal constatação difere das abordagens tradicionais cujo enfoque sobre a democracia geralmente se davam mais no campo acadêmico, negligenciando uma discussão mais aprofundada sobre como os cidadãos percebem a democracia e suas experiências em um regime desse tipo. Uma forma de estudar como as pessoas concebem esse conceito tem sido via pesquisas quantitativas que buscam a confirmação (ou não) de hipóteses préelaboradas. No entanto, quando o conceito de democracia é analisado qualitativamente, do ponto de vista de como os cidadãos experimentam-na, geralmente as teorias estabelecidas e os conceitos mostram-se estreitos e incompletos.

Emblemático dessa situação são os estudos produzidos por Powers (1999), na Argentina, onde constatou que o uso do paradigma poliárquico de democracia é insuficiente para captar a riqueza ou a insuficiência desse conceito. Nesse sentido, a abordagem qualitativa parece a mais indicada para tentar captar a noção de capital social. Pesquisas que mostrem como as pessoas constróem o significado do mundo político tornam-se oportunas e relevantes. No Brasil, principalmente no Rio Grande do Sul e Paraná, vários pesquisadores têm orientado suas preocupações para essa temática, pontualmente com adolescentes. Os dados apresentados na Tabela 1 mostram como, ao longo dos anos, a juventude tem descodificado a política. 
TABELA 1 - AVALIAÇÕES NEGATIVAS DE CATEGORIAS POLÍTICAS (RIO GRANDE DO SUL)

\begin{tabular}{|c|c|c|c|c|}
\hline Categoria/ano & 1994 & 2000 & 2003 & Média \\
\hline Política & 71 & 69 & 75 & 72 \\
\hline Partidos & 72 & 71 & 65 & 69 \\
\hline Governo & 70 & 72 & 69 & 70 \\
\hline Democracia & 86 & 84 & 82 & 84 \\
\hline TOTAL $(N)$ & $(600)$ & $(580)$ & $(1118)$ & - \\
\hline
\end{tabular}

FONTES: para 1994 e 2000: pesquisas sobre socialização política do Núcleo de Pesquisas sobre América Latina (NUPESAL-UFRGS); para 2003: pesquisa sobre o universo político da juventude no inicio do século XXI, em Caxias do Sul (LUCAS, 2003).

NOTAS: 1. A tabela refere-se às respostas à seguinte questão: "Gostaríamos que você colocasse ao lado de cada palavra outra que seja, na sua opinião, parecida, próxima, da palavra sugerida (dimensão negativa)".

2. As respostas agrupadas na dimensão negativa foram: "corrupção", "roubalheira", "mentira", "suja", "ladra", "poder", "falsa", "injusta", "desonesta", "briga", "interesseira", "ruim", "enganadora", "sem caráter", "chata", "confusão", "péssima", "podre" e "mal".

3. Na variável "democracia", as categorias são na dimensão positiva.

Os sintomas de um processo de desconsolidação democrática e, conseqüentemente, de crise de legitimidade do sistema político brasileiro tornam-se evidentes em três áreas, a saber: a percepção negativa e hostil dos cidadãos em relação aos partidos políticos, aos agentes políticos e às instituições políticas.

Há um consenso de que quando as pessoas desconfiam permanentemente da classe política as possibilidades de construir uma democracia eficiente diminuem substancialmente. Se, além dessa desconfiança, os partidos políticos não se constituem em pontos de referência para a construção de identidades coletivas, as relações sociais e políticas dão-se em uma dimensão terciária, ou seja, estabelecem-se relações diretas entre o cidadão e o Estado (Presidente da República), à margem dos partidos. Talvez essa constatação seja a que mais aproxima-se de um teorema, pois a evidência empírica a esse respeito é incontestável.

Outrossim, o fracasso das instituições policial e judiciária em proteger os cidadãos tem propiciado o surgimento de organizações para-estatais que acabam contribuindo para uma imagem negativa do Estado. Como conseqüência, presentemente os cidadãos vivem sob condições de mais insegurança e pobreza.

Essas condições têm criado o que se denomina de um "mercado de desencanto", particularmente com a política e com os políticos. Tal contexto possibilita a desvalorização das virtudes democráticas, que aparecem mais como ficção do que realidade, agravada com o esvaziamento das promessas democráticas. Embora esse desencanto não tenha produzido tolerância pelo autoritarismo, tem gerado sociedades desmobilizadas e apáticas. As pessoas crescentemente se têm retirado da arena pública para a privada, fragilizando qualquer possibilidade de construir uma cidadania democrática, bem como instituições políticas eficientes e estáveis.

Os dados da Tabela 1 confirmam esse diagnóstico, pois constata-se a forma negativa que a juventude internalizou a dimensão política, na última década. As flutuações longitudinais são mínimas e estão dentro da margem de erro. O que está evidente nesse resultado é a prevalência de opiniões preponderantemente hostis em relação às três instituições mencionadas e que são consideradas essenciais na democracia representativa (na média $72 \%$ para a atividade política, $69 \%$ para os partidos políticos e $70 \%$ para o governo). Em relação ao item democracia os dados são opostos, pois se verifica uma orientação majoritária pró-democracia, ou seja, apoio difuso (média $84 \%$ de respostas positivas). 
Os dados refletem, no âmbito da proposta deste artigo, a dificuldade da transição de uma sociedade clientelística para uma sociedade com relações horizontais. Nesse processo, a consolidação da cidadania não é um processo sem dificuldades. Depende de fatores múltiplos que estão envolvidos na transformação de uma cultura política para uma dimensão mais participativa; depende também da proliferação de organizações sociais autônomas e da capacidade dessas associações em representar a pluralidade e diversidade dos distintos interesses existentes na sociedade como um todo; depende também da existência de movimentos sociais democráticos e mecanismos institucionalizados que sejam aplicados para tornar a democracia participativa viável, tais como o referendo, a revogação de mandato e a liberdade de associação.

A leitura dos dados da Tabela 1 sugere que a democracia é possível se existem indivíduos capazes de abstrair-se do particularismo e assumir a imparcialidade, colocando-se no lugar dos outros. Uma democracia de indivíduos racionais, porém auto-interessados, é inconcebível, visto que a racionalidade emerge da cooperação contratual. Os procedimentos dessa cooperação são: a) a participação direta, b) em deliberações públicas, c) das assembléias que ocorrem periodicamente, d) que legislam por meio de consenso ou maioria, e) que designam representantes f) sempre sujeitos a revogação de mandato. Em virtude dessas regras geram-se resultados coletivamente vinculantes, ou seja, decisões moralmente justas. Esse processo não sugere que a sociedade civil constitua-se em uma alternativa ao governo democrático, mas na cessão de um espaço livre em que as atitudes são conservadas e um comportamento democrático é condicionado (BARBER, 1999, p. 9). Alcançar tal objetivo, em um contexto de descrença generalizada, no entanto, é quase impossível. Torna-se imperativo, portanto, examinar elementos que promovam cidadãos ativos. $\mathrm{O}$ conceito de capital social parece útil nessa direção.

\section{CAPITAL SOCIAL}

O capital social é um potencial e poderoso conceito explicativo nas Ciências Sociais. Ao contrário da cultura política, que enfatiza a estabilidade ideológica e a estabilidade das democracias, a teoria do capital social tem no âmago de sua análise o desempenho das instituições democráticas. Putnam (1993) argumenta que as instituições são instrumentos para alcançar propósitos e não meramente concordâncias. Os cidadãos querem que o governo faça coisas e não simplesmente decida coisas. Poder-se-ia dizer que às atitudes e normas propostas pela teoria de cultura política acrescenta-se uma dimensão avaliativa de como fazê-las, de maneira eficiente: é nisso que se constitui o capital social. Esse fator distinto da teoria de capital social levou Foley e Edwards (1997, p. 550) a sustentar que o capital social faz "parte da busca por novos paradigmas com os quais confrontar os problemas das sociedades contemporâneas". Para o Banco Mundial, por exemplo, esse conceito está sendo considerado como o "elo perdido" do desenvolvimento (FINE, 1999), inclusive promovendo uma nova agenda de análise na redução da pobreza e na promoção da democracia social. Assim, seu uso tem possibilitado reflexões alternativas teóricopráticas, conceituações e pesquisas empíricas que permitem que várias áreas de políticas públicas sejam melhor compreendidas. Ao mesmo tempo, é um conceito problemático em vários aspectos, tais como: seu significado, sua medição, se é antecedente ou conseqüente e sua dependência contextual. Suas raízes, além de serem históricas, são multidisciplinares (Putnam na Ciência Política; Coleman na Sociologia; Fukuyama na História Econômica e na Sociologia). Do ponto de vista ideológico, em uma dimensão contínua, o capital social pode ser o empowerment da cidadania, o pluralismo e a democratização. Em uma dimensão mais conservadora, o capital social localiza-se em um compromisso com estruturas familiares tradicionais e em uma ordem moral coletiva fundada em valores tradicionais (GAMARNIKOV \& GREEN, 1999). As definições mais conhecidas são aquelas que vinculam o capital social à confiança nas relações sociais (FUKUYAMA, 1995), como engajamento cívico via participação em associações voluntárias (PUTNAM, 1995), como uma fábrica social que cria o desejo de cooperar no desenvolvimento de capital físico (OSTROM, 1994) como uma variável na geração de capital humano entre gerações e como um aspecto da estrutura social que facilita determinadas formas de ação e cooperação.

Uma diferença importante entre capital social e outras formas de capital é que o capital social existe em uma "relação social". Reside nas "relações" e não no indivíduo sozinho, como é o caso 
de habilidades de capital humano. É construído em coletividades institucionalizadas tais como: universidades, corporações, governos, associações informais de pessoas em que o conhecimento e as visões de mundo formam-se e são transferidas.

Obrigações, confiança, fluxo de informações, amigos, cultura, normas, redes e engajamento cívico constituem-se em indicadores parciais sobre o que é o capital social e onde reside. Se a metáfora de bens e capitais é útil para analisar as relações sociais, deve ter em conta a habilidade transformadora do capital de uma coisa para outra. $\mathrm{O}$ que nas relações sociais funciona como um catalisador de ações coletivas e cooperativas? Os economistas têm enfatizado principalmente o motivo individual ou a maximização de utilidades (ambição). Se as pessoas confiam umas nas outras, honram as obrigações, seguem as normas e tornam-se amigos uns dos outros, somente para maximizar sua própria a utilidade, esses elementos são simplesmente commodities adicionais para serem intercambiados.

É necessário, portanto, acrescentar outras variáveis que esclareçam como o capital social funciona. Por exemplo, a simpatia, um indicador difícil de ser operacionalizado quantitativamente, pode gerar envolvimentos unilineares que não são calculados necessariamente com a expectativa de retorno. A esse respeito, os sociólogos e os analistas políticos afirmam que o comportamento que segue normas e obrigações não é calculado estritamente, mas é apreendido na socialização, é um esforço parcialmente inconsciente. Os indivíduos interagem, formam e são formados por esses processos culturais.

Visto dessa perspectiva, o capital social é um recurso complexo que oferece explicações sobre como os dilemas da ação coletiva podem ser superados; muitos autores sustentam que têm um impacto significativo e relevante na obtenção de resultados importantes de políticas públicas em áreas como: educação, saúde, criminalidade, bemestar, crescimento econômico, desempenho de instituições políticas e desenvolvimento de governos efetivos e democráticos (MALLONEY, SMITH \& STOKER, 2000, p. 802). Apesar das criticas ao conceito, Trigilia (2001, p. 428) argumenta que, se usado com cuidado e precisão e se não estiver sobrecarregado, o conceito de capital social pode ajudar-nos a compreender não só o desenvolvimento local, mas principalmente a formulação de políticas mais apropriadas - embora ressalte que o capital social não deve ser visto em termos de cultura ou civilidade, mas em termos de relações e redes sociais.

A premissa essencial do capital social é a de que permite ações cooperativas comunitárias e resolve os problemas comuns da coletividade. Assim, o conceito de capital social é atraente porque agrega um número de características da vida social principalmente para aspectos negligenciados ou escondidos da vida política de uma cidade. Desafia-nos a explorar a infraestrutura da sociedade civil e sugere que dentro dela podemos encontrar explicações sobre como em algumas localidades a atividade política e, principalmente, econômica e social mostram grande vitalidade e parecem ser mais efetivas. Tal hipótese tem-se consolidado ao longo do tempo com estudos que têm verificado tal relação (PUTNAM, 1995; principalmente, NARAYAN \& CASSIDY, 2001).

Paradoxalmente, a polêmica e a controvérsia a respeito do significado do capital social tem-se constituído uma fonte de estímulo à realização de estudos e pesquisas, ao invés de marcar seu declínio. Do ponto de vista teórico, por exemplo, tenta-se construir conceitos intermediários, dentro dos quais se incluem anomalias empíricas e analíticas que inevitavelmente surgem da existência de redes e da confiança. Outrossim, a noção de causalidade entre capital social e resultados específicos pode ser revertida ou redefinida.

Está claro que, presentemente, as dimensões de capital social (tais como: confiança das relações entre os indivíduos e instituições; redes e canais informativos; normas e sanções efetivas) são de importância fundamental na formação da vida econômica e social. O capital social é considerado produtivo, pois torna possível alcançar determinados objetivos que na sua ausência não seria possível.

A valorização das associações livres como ingredientes verdadeiros dos sistemas democráticos, portanto de capital social, não é novo: remonta a Montesquieu, Tocqueville e Weber. O último, por exemplo, embora não utilizasse o termo "capital social" no seu trabalho sobre a ética protestante, já concebia a idéia de redes sociais como instrumento para influenciar a formação de atividades empresariais, facilitando assim o desenvolvimento econômico em uma área parti- 
cular. O que importa ressaltar é que, da mesma forma que muitos autores contemporâneos, Weber avaliou positivamente os resultados e as consequiências dessas redes de relações sociais para a atividade econômica.

De fato, todas as constituições do mundo liberal-democrático explicitam, de alguma forma, a necessidade de assegurar e garantir a liberdade de associação. Nos últimos anos, essa idéia tem ocupado grande espaço de debate, principalmente a premissa central de Putnam (1993; 2000), para quem a problemática central da saúde das sociedades contemporâneas localiza-se no envolvimento dos cidadãos com associações não-políticas como requisito essencial da constituição de normas e valores de adesão à democracia. Nesse sentido, "as associações são as principais escalas da democracia na sociedade" (ROBTEUTSCHER, 2002, p. 514).

Essa afirmação, no entanto, tem sido contestada do ponto de vista quantitativo, pois argumenta-se que existe pouca evidência de que fazer parte de associações voluntárias está relacionado a atitudes individuais de confiança (NEWTON, 2001, p. 201). Baseado nesses resultados afirmase que as teorias que associam capital social, sociedade civil e estabilidade democrática são frágeis. Creio que a questão não está na ausência de solidez teórica, mas sim na forma, ainda não resolvida, de como se mede a confiança e o capital social. É mais provável que os indicadores empíricos não estejam captando essa associação, pois seria inconsistente defender que a integração social, a eficiência econômica e a estabilidade democrática possam ser alcançadas, embora a história mostre que em alguns casos seja possível, mesmo sem confiança por parte dos cidadãos nas instituições e nos governantes. A existência de confiança não só cria um ambiente de credibilidade e, conseqüentemente, de legitimidade, como fortalece o contrato social. A ausência desse elemento gera tensão permanente e instabilidade na sociedade que, no máximo, pode aspirar a uma democracia instável em que mecanismos de engenharia institucional não raro parecem medidas casuísticas e descontextualizadas. A esse respeito DaMatta tem observado que "achar que nós vamos modificar profundamente e sanar determinados males modificando simplesmente a arquitetura institucional, eu realmente acho uma coisa terrível" (DAMATTA, 1993, p. 55). Esse seria um dos elementos, segundo o autor, que explicaria porque os brasileiros sistematicamente vivem sob regimes cujo funcionamento é autoritário, embora democraticamente eleitos.

Talvez por isso tanto Tocqueville como Putnam tenham estabelecido uma associação próxima entre confiança, normas, virtudes cívicas em geral e associações, de um lado, e um processo democrático eficiente, por outro. A credibilidade de um sistema político e seu eficiente desempenho, portanto, depende do grau de confiança que as pessoas têm nas instituições.

Assim, a legitimidade de um sistema político é construída por meio de fatores institucionais, históricos e culturais. Na dimensão da cultura política são as atitudes de satisfação demonstrada pelos cidadãos em relação à democracia que nos dão indícios sobre o grau de legitimidade e credibilidade do sistema político. Esse indicador é clássico e vem dos tempos de David Easton (1965), para quem essas atitudes possibilitam determinar o que ele denominou de apoio difuso, que era considerado essencial no processo de construção de legitimidade das instituições políticas. Apesar das críticas feitas aos conceitos de apoio difuso e apoio específico, consideramos que, pelo menos até os dias de hoje, os aspectos positivos e sua contribuição na compreensão das bases de legitimidade superam as deficiências apontadas por vários autores (NORRIS, 1999). Porém, o conceito mais importante na compreensão da estabilidade de um sistema político tem a ver com o apoio dos cidadãos às instituições da poliarquia.

A esse respeito torna-se oportuno examinar o grau de confiança dos brasileiros em suas instituições políticas; esses dados estão apresentados na Tabela 2. 
TABELA 2 - GRAU DE CONFIANÇA DOS BRASILEIROS NAS INSTITUIÇÕES POLÍTICAS (\%)

\begin{tabular}{|c|c|c|c|c|c|c|c|c|}
\hline $\begin{array}{c}\text { Instituições/ } \\
\text { ano }\end{array}$ & 1968 & 1974 & 1985 & 1994 & 1996 & 1998 & 2000 & 2002 \\
\hline $\begin{array}{c}\text { Governo } \\
\text { Federal }\end{array}$ & 40 & 48 & 56 & 70 & 83 & 82 & 92 & 87 \\
\hline $\begin{array}{c}\text { Congresso } \\
\text { Nacional }\end{array}$ & - & - & - & 84 & 87 & 86 & 92 & 89 \\
\hline $\begin{array}{c}\text { Partidos } \\
\text { Políticos }\end{array}$ & - & - & 40 & 66 & 60 & 90 & 89 & 91 \\
\hline TOTAL $(N)$ & 367 & 380 & 488 & 600 & 600 & 600 & 600 & 600 \\
\hline
\end{tabular}

FONTE: Pesquisas eleitorais em Porto Alegre (NUPESAL-UFRGS).

NOTA: A tabela refere-se à pouca ou nenhuma confiança dos entrevistados nas instituições indicadas.

As respostas dos entrevistados em relação ao grau de confiança que eles depositam nas instituições políticas - neste caso o governo, o Poder Legislativo e os partidos - mostram que os cidadãos não confiam nelas. A confiança nas instituições não é somente uma dimensão atitudinal de valor positivo do ponto de vista moral e ético, é também imperativo para o fortalecimento da democracia. Em sociedades caracterizadas pela desconfiança prevalecem as atitudes e comportamentos políticos tradicionais, em que o clientelismo, o personalismo e o patrimonialismo são práticas do cotidiano político. O mais preocupante dos dados acima é o gradual crescimento dessa desconfiança, mesmo no âmbito de um regime democrático. A persistência desses níveis elevados de desconfiança pode constituir-se em um indício fundamental para entender a crise permanente dos governos popularmente eleitos no país, nos últimos anos. Quando menos de 20\% da população confia nas suas instituições (de 1996 a 2002), é difícil falar em "consolidação democrática".

Segundo essa evidência que mostra as insti- tuições políticas à margem da vida das pessoas, é inevitável que os cidadãos voltem-se para outros interlocutores nas suas reivindicações - as associações informais. Esse comportamento não é novo, pois desde a publicação do livro Political Culture de Almond e Verba, tem-se acumulado grande quantidade de evidências empíricas que mostram que as associações têm um impacto positivo na saúde democrática dos países. Constatou-se que a correlação está condicionada pelas condições históricas estruturais de um país, ou seja, não se pode concluir que a relação participação em associações voluntárias - fortalecimento democrático seja causal. Isso se deve ao fato de que as associações não fomentam, por si sós, um tipo de cultura política, mas são um reflexo de e amplificam os traços culturais dominantes de seu ambiente. $\mathrm{Na}$ verdade, constituem-se no espelho da cultura política vigente.

Robteutscher (2002, p. 516) apresenta o seguinte esquema para avaliar a diferença entre a perspectiva do capital social e a perspectiva histórica.

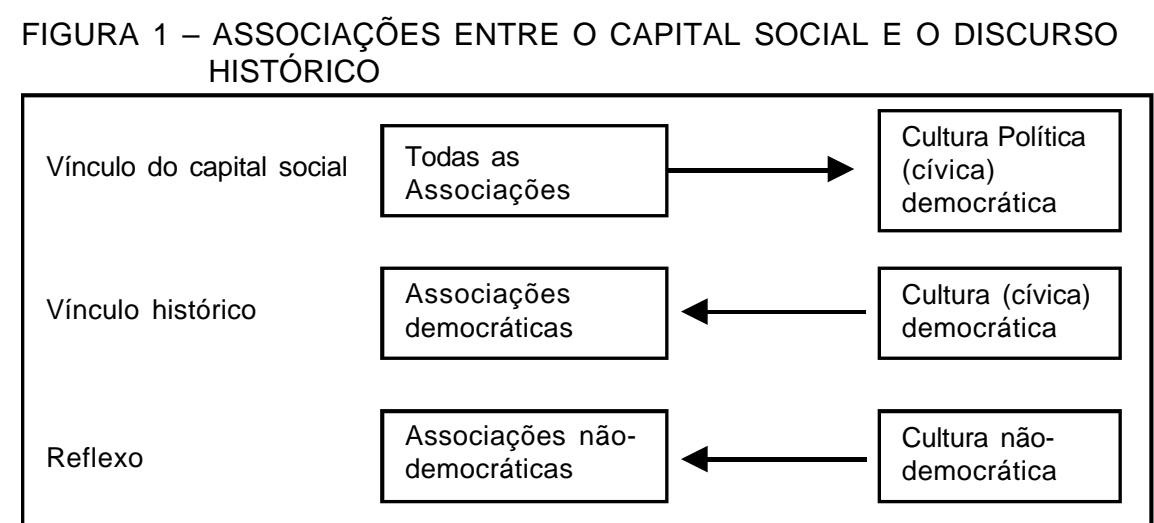

FONTE: Robteutscher (2000, p. 516). 
Esse esquema é valioso na compreensão de como uma cultura política é construída, pois ilustra como os chamados fatores histórico-estruturais incidem nessa configuração. Não se trata de um determinismo histórico ou cultural, mas sim da influência de um legado que incide na forma como os valores e crenças internalizados pelas pessoas afetam a qualidade da democracia de um país. Se esses valores e normas são negativos a possibilidade de substituir uma ordem social é remota, pois valores e crenças são o fundamento da institucionalidade democrática. No Brasil, segundo Fernandes (1968), o problema histórico da política é o ethos patrimonialista. Segundo o autor, são quatro séculos de mandos e desmandos clientelistas. Isso fez que o conflito (a lógica da política) fosse tratado desde os primórdios da República como caso de polícia, exclusão e antagonismo social exacerbado, produzindo uma estrutura política autoritária que vige até os dias atuais. Tal contexto histórico não pode ser negligenciado para compreender porque os cidadãos brasileiros não confiam nas suas instituições políticas, ao mesmo tempo que permite compreender porque a mera existência de condições estruturais para que a democracia fortifique-se é insuficiente.

Por exemplo, se se institucionaliza na sociedade o medo e a insegurança coletivos, as células sociais são praticamente destruídas, não possibilitando o desenvolvimento de normas, tais como: solidariedade, confiança e tolerância. No seu lugar, constitui-se uma cultura política de resignação a práticas autoritárias, verticais, hierarquizadas, mesmo em um regime democrático. Tais atitudes e comportamentos negam a possibilidade de produzir mecanismos institucionais de mediação política com credibilidade. Tal situação dificilmente contribui para a solidificação de uma cultura política participativa.

Esse dilema fez que a agenda do período recente de democratização no Brasil tenha-se voltado para a busca de diretrizes de inclusão social e política dos cidadãos na sociedade moderna. Essa tarefa, entretanto, exigiu o resgate de conceitos que haviam sido considerados pouco úteis na compreensão dos dilemas democráticos, tais como: clientelismo, personalismo e patrimonialismo. Esses conceitos, por exemplo, são utilizados por Bruso, Nazareno e Stokes (2001) para examinar por que na Argentina os eleitores, apesar de terem sido traídos por promessas eleitorais que não se materializaram após seus candidatos serem eleitos, continuaram a apoiar o partido político e os políticos que frustraram suas expectativas; a explicação dos autores é que o clientelismo de Menem funcionou na cooptação dos pobres. O mesmo fenômeno ocorreu no Peru, com Fujimori, e no Equador, com Bucharam e depois com Mahuad. Exemplos como esses não são incomuns nos países da América Latina, e o Brasil não é a exceção. Candidatos notoriamente conhecidos por suas práticas autoritárias, populistas e com pouco teor ético e moral continuam a ser eleitos. Nesse contexto, o legado cultural das instituições tanto formais quanto informais são o reflexo da forma como as relações sociais são absorvidas pela cultura - em um sentido clientelístico.

Esse contexto faz que a política e suas instituições sejam vistas de maneira negativa, propiciando a emergência de modos alternativos de transmissão de demandas; esses canais alternativos fundamentam-se, em parte, na corrupção, em uma burocracia ineficiente, na supressão de liberdades civis, nas falhas na esfera dos direitos de propriedade e no fracasso na manutenção da coesão. No caso do Brasil, tais fatores caracterizaram sua história obrigando as comunidades a tentar resolver por si mesmas problemas que são da responsabilidade do Estado, em um sentido privado e informal. Isso se deve ao fato de que as pessoas não vêem nessas instituições méritos ou vêem-nas com desconfiança, de modo que o distanciamento delas é inevitável. Quando os mecanismos de representação convencionais (partidos políticos) não conseguem expressar ou agregar os interesses da população, por meio de um consenso democrático, a crise decorrente dessa situação leva a um funcionamento atípico das instituições democráticas os grupos tradicionalmente marginalizados continuam a ser excluídos da agenda dos partidos. Tal situação conduz à prevalência do clientelismo e do particularismo (os interesse particular sobrepõe-se ao bem público) que, por sua vez, possibilita um cinismo generalizado em relação às instituições formais da poliarquia (PARAMIO, 1999). Nesse contexto, os partidos servem para agregar votos e não preferências, não possibilitando a formulação de políticas públicas de interesse geral (LYNE, 1997). Não surpreende que, nessas circunstâncias, as pessoas não demonstrem interesse em filiar-se ou identificar-se com partidos políticos. Os dados da Tabela 3 são ilustrativos desse distanciamento, no caso do Rio Grande do Sul. 
TABELA 3 - IDENTIFICAÇÃO PARTIDÁRIA NO RIO GRANDE DO SUL (\%)

\begin{tabular}{|c|c|c|c|c|c|c|}
\hline Partido/ano & 1974 & 1985 & 1994 & 1996 & 1998 & 2000 \\
\hline ARENA & 18 & - & - & - & - & - \\
\hline MDB & 41 & - & - & - & - & - \\
\hline N/S ou N/R & 11 & - & - & - & - & - \\
\hline PDS & - & 6 & - & - & - & - \\
\hline PDT & - & 28 & 8 & 5 & 7 & 8 \\
\hline PT & - & 6 & 29 & 41 & 33 & 40 \\
\hline PTB & - & 2 & 2 & 2 & 3 & 4 \\
\hline PMDB & - & 21 & 11 & 3 & 10 & 5 \\
\hline PFL & - & 2 & 2 & 3 & 1 & - \\
\hline PCdoB & - & 1 & 0,5 & - & 0,4 & - \\
\hline PFL & - & 2 & 2 & 3 & 1 & 1 \\
\hline PSDB & - & - & 1 & 2 & 1 & - \\
\hline Nenhum & 28 & 30 & 41 & 32 & 34 & 30 \\
\hline TOTAL $(N)$ & 380 & 600 & 600 & 600 & 600 & 600 \\
\hline
\end{tabular}

FONTE: Pesquisas eleitorais em Porto Alegre (NUPESAL-UFRGS).

NOTAS: 1 . Os totais podem não somar 100\% em virtude da não inclusão de preferência abaixo de $1 \%$.

2. N/S ou N/R: não sabe ou não respondeu.

No período de 1994-2000, a magnitude da identificação partidária favorece claramente o Partido dos Trabalhadores (PT), em detrimento de todos os outros partidos, que experimentam um declínio ou estagnação constantes. O que chama atenção, entretanto, é manutenção da não identificação partidária acima de $30 \%$ nesses quase 20 anos, revelando que os partidos pouco têm feito para motivar os cidadãos a filiarem-se ou mesmo identificarem-se com eles. Como se sabe, um dos elementos considerados essenciais para a estabilidade política de uma nação é o grau e a estabilidade com que as pessoas se identificam com as organizações mediadoras de seus interesses. Presume-se que com o processo de convivência democrática, ao longo do tempo, essa identificação tenda a aumentar. O que se observa, entretanto é uma estagnação e até um processo de desinstitucionalização dos partidos. Esses dados mostram que a possibilidade de desenvolver estímulos para um engajamento político maior dos cidadãos não se dá por meio dos partidos políticos. A produção de capital social, tendo como catalisador os partidos, é mínima. Os eleitores procuram outras fontes de motivação para envolver-se politicamente. De maneira geral, podese afirmar que os partidos, inclusive em um estado considerado politizado como o Rio Grande do Sul, baseiam a representação de interesses muito mais no intercâmbio particularizado, razão por que a maioria dos eleitores carece de identidade ideológica. Não surpreende, portanto, que os cidadãos procurem outros mecanismos de agregação de seus interesses. Nesse caso, podem ser apontadas as associações secundárias e voluntárias.

A hipótese na literatura é que a participação em associações produz capital social relevante, o que significa que promove e facilita o engajamento político. Esse tipo de capital social é produzido como conseqüência da experiência política e da 
informação que é regularmente comunicada dentro da rede de relações sociais do indivíduo.

Uma das postulações mais consistentes que se tem estabelecido na discussão sobre a democracia é a de que, sem confiança, ela não sobrevive. Seu fortalecimento, portanto, depende do fim do monopólio da representação e agregação de interesses centrada nos partidos. As circunstâncias atuais exigem outras formas de agregar demandas. Embora o capital social seja fomentado por uma variedade ampla de interações formais e informais entre os membros de uma comunidade, uma análise plena dessas interações não é observável. O que se pode observar é a prevalência de filiação em organizações voluntárias em um determinado contexto. Como resultado, ser membro de associações tem-se tornado o indicador mais adequado para examinar a formação ou destruição de capital social. Acredita-se que, ao fazer parte de associações, as pessoas desenvolvem interações entre si, aumentando a possibilidade do desenvolvimento de confiança recíproca entre elas. O resultado, segundo pesquisas (YAMAGISHI \& YAMAGISHI, 1994), é o aumento da capacidade da ação coletiva, cooperação e confiança intragrupo, possibilitando que os objetivos coletivos sejam alcançados mais facilmente. A questão fundamental, entretanto, é saber se a participação em grupos e associações também contribui para o processo de construção de uma sociedade em que a cooperação para todo e qualquer propósito - não somente dos grupos - é facilitado (STOLLE \& ROCHON, 1998). Nessa direção, as associações, em um sentido amplo, podem ser o caminho a seguir. Outrossim, pressupõe-se que a experiência de ser membro de associações formais ou informais contribui para o desenvolvimento da tolerância e cooperação entre os cidadãos de maneira geral. $\mathrm{O}$ teorema é de que quanto mais a pessoa participa de associações, maior a tendência a solidificar um civismo público e, conseqüentemente, o fortalecimento da democracia. Tais qualidades, tolerância e cooperação, somente geram confiança generalizada quando se orientam para a comunidade como um todo, o que não é o caso de bandos, a máfia, ou grupos fanáticos que podem produzir capital social personalizado, mas não produzem capital social público que é o que conta para o amadurecimento democrático de um país.

Nessa direção, o que nos interessou foi examinar a experiência das pessoas em associações em um sentido mais genérico e público na capital gaúcha, pois o capital social público constitui-se na essência da tese do capital social.

TABELA 4-GRAU DE ASSOCIATIVIDADE EM PORTO ALEGRE (1974-2000) (EM \%)

\begin{tabular}{|c|c|c|c|}
\hline Ano/resposta & 1974 & 1998 & 2000 \\
\hline Sim & 34 & 17 & 22 \\
\hline Não & 68 & 83 & 78 \\
\hline
\end{tabular}

FONTE: Pesquisas eleitorais em Porto Alegre (NUPESAL-UFRGS).

NOTA: A tabela refere-se às respostas à seguinte questão: "O(a) sr(a). participa de algum tipo de associação (religiosa, esportiva, outra)?".

Embora a análise dos dados diga respeito às pessoas, o capital social pressupõe objetivos tangíveis de natureza coletiva (por exemplo, unir esforços para conseguir o asfaltamento de ruas); assim, o capital social público refere-se à unidade de análise "macro" e não "micro". Os dados examinados nos anos 1974, 1998 e 2000 sugerem níveis reduzidos de associatividade dos cidadãos em Porto Alegre. O que chama a atenção é a percentagem relativamente elevada de pessoas que responderam participar de algum tipo de associação em 1974 (34\%): seria lógico esperar que tal nível fosse mais razoável para os anos subseqüentes, pois foi a época da chamada consolidação democrática (1998-2000). Para tentar compreender o que estava acontecendo, essa variável foi cruzada com o tipo de associação a que o cidadão vinculou sua participação. A resposta foi esclarecedora. Em 1974, 76\% das pessoas responderam participar de algum tipo de associação religiosa, indicando sua igreja como a fonte primária de tal vínculo, caindo para $67 \%$ 
em 1998 e 51\% em 2000. O que se depreende dessas informações é que, a partir de 1974, o declínio em associatividade dos cidadãos coincide com o declínio da credibilidade das instituições políticas como fontes de construção de identidades coletivas. Esse declínio, no entanto, aparentemente não foi substituído por vínculos com outro tipo de associações - que experimenta, ao contrário do esperado, uma redução. O ideal seria poder contar com dados de pesquisa do tipo painel que nos possibilitassem uma avaliação das flutuações atitudinais em relação às razões que levaram as pessoas a não se interessarem em participar de outras associações. $\mathrm{Na}$ ausência dessas informações, no entanto, pode-se levantar uma hipótese de que pertencer ou ser membro de igrejas é uma atividade quase formal e obrigatória, não produzindo estoques de capital social público que se possam transferir para outras associações, conforme os dados parecem sugerir. Do ponto de vista empírico, pelo menos, a evidência de uma tradição de associatividade pública em Porto Alegre deve ser vista com cautela.

A hipótese que aqui se levanta é que é imperativo fomentar e fortalecer as associações voluntárias e públicas existentes como instrumentos vitais do amadurecimento democrático pela participação ativa e propositiva, da intelectualidade do país, indo além de uma prática meramente descritiva e de diagnóstico. Para Verba et alli (1995), por exemplo, um dos principais resultados da existência de associações é que elas proporcionam um espaço para que as pessoas discutam a política mais freqüentemente, estimulando seu interesse, sofisticação e participação política.

A associação, por outro lado, quando espontânea e voluntária, ao contrário de obrigatória, possibilita conhecer outras pessoas, aumentando não só a possibilidade de mais discussões políticas, como aumenta a percepção do indivíduo do que está ocorrendo na sociedade e a maneira dominante e aceita da forma de pensar e agir.

Assim, pressupõe-se que as associações civis são mais democráticas e mais cívicas porque existem em sociedades que são mais democráticas e mais cívicas do que sociedades do passado. As evidências mais citadas na América Latina dessa situação são: a criação de Villa el Salvador, no Peru; as feiras de consumo popular, na Venezuela, e o orçamento participativo, em Porto Alegre (KLIKSBERG, 2000).
No entanto, vários autores têm alertado para a importância de reavaliar a relação causal entre associações e bom governo. Portes (1998), por exemplo, tem sugerido que o impacto de redes sociais nas atividades econômicas pode ser muito diferente. Segundo ele, se, de um lado, em muitos casos a informação e confiança que circulam por meio das relações pessoais podem limitar o oportunismo e facilitar a cooperação econômica, de outro lado podem agir como limitadores de competitividade e assim reduzir a eficiência como resultado dos conflitos entre os atores. Portanto, para compreender de que forma as funções positivas decorrentes da existência de redes sociais podem ser materializadas é primordial conhecer não só as condições culturais, mas também as políticas.

A reflexão de Portes é valiosa no sentido de apontar a necessidade de levar-se em consideração o contexto histórico e cultural dentro do que o capital social é (ou não) gerado. No caso brasileiro, apesar de os dados não englobarem o conjunto do país, pode-se inferir teoricamente que não há uma tradição associativa e a que existe não proporciona as bases de produção de capital social público. Dessa forma, apesar da existência de centenas de associações informais e voluntárias que organizamse em torno de objetivos comuns, elas parecem não gerar redes associativas mais amplas, pois seus membros centram-se em questões particulares. Esse, por exemplo, tem sido o problema do orçamento participativo em Porto Alegre (GENRO, 2001; RICCI, 2001).

Assim, a história mostra que o monopólio da representação e participação política no Estado e nos partidos políticos no Brasil está longe de constituir-se no elemento catalisador de uma qualidade democrática melhor, contribuindo para o crescente ceticismo do cidadão em relação às instituições políticas. Nesse contexto, o Estado de Direito é permanentemente questionado e é imprevisível e as estruturas burocráticas não funcionam de acordo com valores universais. Dito de outra forma, em um contexto em que o Estado é ineficiente e com pouca credibilidade, as redes sociais podem aumentar o desenvolvimento do conflito tanto na atividade econômica como nas instituições públicas em uma dimensão negativa, levando à apropriação de recursos políticos e conseqüentemente à institucionalização de relações pautadas por clientelismo e paternalismo. Esse parece o caso do Brasil contemporâneo. 
Nesse sentido, a construção de capital social público deve ser analisada dentro de uma compreensão da evolução histórica e das condições materiais do país, além de considerar-se como um processo de interações sociais que levam a resultados construtivos. Não depende, portanto, de um único fator e também não é uma relação linear (BANKSTON \& ZHOU, 2002, p. 285).

\section{AS BASES DE LEGITIMIDADE DO SIS- TEMA POLÍTICO BRASILEIRO}

Vários autores brasileiros, ao longo do tempo, têm argumentado que o legado histórico do país não possibilitou o estabelecimento de bases sólidas para constituição de uma democracia duradoura no sentido social (Viana, Amaral, Tavares, Hollanda, Uricochea). Um dos elementos responsáveis por tal situação é, segundo os autores, a incapacidade das instituições em constituírem-se em pontos de referência para a construção de identidades coletivas na sociedade. Os dados da Tabela 4, acima, demonstram claramente que, longitudinalmente, a desconfiança nessas instituições, mesmo na vigência da redemocratização, mantém-se inalterada.

Para o caso do Brasil, quando se examina qual a contribuição das instituições governamentais da democracia formal na produção de capital social público, constata-se que, ao contrário do que se esperava, o que essas instituições produzem não é capital social mas fragmentação e apatia por parte dos cidadãos.

O argumento de Eduards e Foley (1997) - de que o capital social é específico de um determinado contexto, existindo nas relações e normas sociais que facilitam a ação cooperativa e que existem dentro dos grupos não é necessariamente transferível para outros contextos - é oportuno a esse respeito. Se aceito o argumento de contextualidade, então não há sentido em medir o capital social no nível individual fora da comunidade específica. Talvez isso ocorra porque a atenção tem-se orientado para o papel das associações voluntárias e civis, negligenciando parcialmente o papel da família, da escola e do lugar de trabalho no debate sobre capital social.

Em um sentido mais abrangente, o capital social deve incorporar a família, os amigos e os colegas de trabalho como elementos constituidores de um recurso importante se que pode catalisar em épocas de crise ou em situações que requeiram alcançar bens materiais coletivos. Assim, aquelas comunidades com elevados estoques de redes sociais e associações cívicas estão em uma posição mais sólida para enfrentar vulnerabilidades, a pobreza, resolver disputas e/ou tirar partido de novas oportunidades (WOOLCOCK, 2001). É esse, por exemplo, um dos argumentos utilizados para explicar o sucesso do orçamento participativo em Porto Alegre. Afirma-se que essa cidade detém uma dimensão de sociabilidade igualitária que contribuiu na formação de elementos associativos mais fortes que no resto do Brasil (AVRITZER, 2003, p. 20), promovendo, assim, predisposições associativas que facilitaram a implantação de uma democracia mais participativa.

A evidência mais sólida em apoio da tese do capital social vem de estudos no nível comunitários (cívico), que se utilizam de medidas sofisticadas de redes comunitárias, da natureza e da abrangência da participação cívica e dos intercâmbios entre vizinhos. Dessa forma, para que a democracia funcione a confiança e as redes representam précondições necessárias, porém não suficientes. Uma sociedade pode ter elevados índices de confiança entre os cidadãos, ou pode estar interconectada com redes sociais horizontais, mas para que esses recursos sejam relevantes para a democracia as pessoas devem preocupar-se com assuntos que vão além de suas vidas privadas. Aqui o papel do Estado, nos seus vários níveis, e a comunidade acadêmica tornam-se insubstituíveis, pois são esses agentes que podem articular a construção de capital social em um sentido mais amplo e mais abrangente.

Essa participação pode gerar efeitos internos e externos no sistema político. Externamente as associações podem passar a ser vistas como canais alternativos de influência, pois proporcionam vínculos institucionais entre os membros e o sistema político e servem como instituições intermediárias. A articulação e agregação de interesses, bem como de valores, é facilitada pela presença de densas redes de associações secundárias (PUTNAM, 1993).

No nível interno, o resultado pode se dar na geração de hábitos de cooperação, solidariedade e espírito público. É um processo de socialização. Outrossim, tem também um efeito educacional porque os participantes adquirem habilidades e competências que são importantes para a democracia: por exemplo, conhecimento sobre temá- 
ticas específicas ou como as instituições públicas funcionam, como administrar a organização, como discutir assuntos de "maneira civilizada"... dessa forma, as associações podem constituir-se em escolas de democracia.

Nos últimos anos têm proliferado associações terciárias cujo apoio dá-se por meio de contribuições monetárias ao invés da participação com tempo. Assim, constata-se que há um declínio na intensidade de envolvimento associacional. Sabese que o capital social pode formar-se e transmitirse por interação direta; por outro lado, grupos terciários consistem em redes verticais e não horizontais, conseqüentemente não contribuindo para o desenvolvimento de redes horizontais ou da confiança social.

Assim, redes verticais contribuem pouco para resolver problemas coletivos. Segundo Putnam (1993, p. 74) uma rede vertical, independentemente de sua densidade e da importância para seus participantes, não pode sustentar confiança e cooperação. Em contrapartida, as associações fomentam um maior grau de horizontalidade. A associação cria redes secundárias que promovem a interação face-a-face com poucas barreiras para os "de fora" e com os participantes envolvidos em associações múltiplas. No nível individual, afiliações múltiplas significam uma interação mais ampla. Conseqüentemente, deve ter um efeito cumulativo no nível de confiança e engajamento cívico e deve ampliar o escopo de redes que facilitam sua difusão na sociedade. Em pesquisa empírica levada a cabo na Noruega, Wollebaek e Selle (2002, p. 44) demonstraram que a participação tem um impacto na confiança social inclusive quando se controla pelas características demográficas. A forma mais produtiva de participação em relação à formação de capital social parece ser não apenas a participação em várias associações mas afiliações múltiplas em associações com propósitos diferentes.

Um dos aspectos centrais de capital social é o de entender a democracia por meio da transformação das relações de poder entre o Estado, o mercado e a sociedade civil. A idéia de democracia implícita nesse tipo de descentralização transcende a de função estritamente processual de uma democracia como um sistema político caracterizado por eleições livres, baseado no sufrágio universal, liberdade de associação, accountability e controle civil dos militares (O’DONNELL, 1992).

\section{CONCLUSÃO}

Uma das teses que se tem solidificado na teoria política contemporânea é a que diz respeito às virtudes da democracia participativa vis-à-vis a democracia representativa. Estudos com diferentes metodologias e perspectivas teóricas têm crescentemente convergido para a idéia de que é imperativo resgatar o cidadão para a esfera pública. Tanto a legitimidade e a credibilidade de um sistema político dependem não só das instituições políticas da engenharia institucional, dos fatores externos e internos, mas também de uma base normativa de apoio a essas instituições por parte dos cidadãos. Há um consenso de que sem confiança não há democracia. Presume-se que o processo de construção de bons cidadãos passa por um engajamento mais eficiente e permanente na arena política. São as associações que facilitam essas atividades, pois elas constituem-se em escolas de cidadania onde se aprende, fundamentalmente, as virtudes da cooperação e da tolerância. Isso não significa um posicionamento que favoreça ou insinue a diminuição ou enfraquecimento das instituições típicas do sistema representativo de democracia. O contexto contemporâneo, entretanto, caracteriza-se pelo surgimento de um conjunto de fatores novos e inesperados que não foram contemplados pelos teóricos da democracia de procedimentos e que estão obstaculizando a construção eficiente de um sistema democrático orientado para o social. Para deter esse processo de fragmentação societária por meio do capital social é necessário fortalecer a ação coletiva. Três componentes são essenciais para alcançar esse objetivo: confiança; desenvolvimento de redes sociais e fomento ao engajamento cívico.

São esses instrumentos, além dos mecanismos convencionais, que poderão proporcionar bases alternativas que complementarão as políticas convencionais para resolver os problemas contemporâneos da sociedade brasileira: a desagregação social, a fragmentação societária, a erosão da confiança interpessoal e nas instituições políticas, a crise econômica e o crescimento da pobreza e da exclusão social. Tais fatores e sua superação não dependem de mais leis, mais instituições e mais regras. Em muitos casos esses procedimentos já estão previstos na Constituição: os problemas são sua implementação e os mecanismos de fiscalização do cumprimento de tais dispositivos. Dois exemplos são suficientes para ilustrar essa 
situação: o cumprimento constitucional de um salário mínimo e o tratamento igualitário dos cidadãos. A sua inobservância não se deve à ausência da palavra escrita, mas à ausência de vontade política e de mecanismos eficientes de fiscalização.

Portanto, a importância renovada sobre papel da cultura política no processo de fortalecimento democrático do país nas teorias modernas de sociedade cívicas sugere que atividades deliberativas face a face e a colaboração horizontal dentro das organizações voluntárias longe da esfera política (tais como: clubes esportivos, cooperativas agrícolas ou grupos filantrópicos) promovem a confiança interpessoal e fomentam a capacidade de trabalho conjunto no futuro, criando os elementos de coesão da vida social que são as bases da sociedade civil e da democracia. Os dados aqui examinados sugerem a existência de uma cultura política pouco participativa, tanto na dimensão convencional quanto na dimensão associativa, mas, ao mesmo tempo indica a necessidade de organizar os grupos já existentes, bem como promover a formação de associações para alcançar metas instrumentais, bem como para criar as condições para uma cooperação mais ampla ou capital social público. Subjacente a essa argumentação está a importância atribuída ao conceito de confiança. A valorização desse conceito pode ser atribuída a uma conscientização ampla de que as bases existentes de cooperação social, solidariedade e consenso têm experimentado uma erosão e que há uma necessidade de procurar outras alternativas. Para Misztal (1998, p. 12), a confiança, entendida freqüentemente em termos vagos e genéricos, condiciona todos os aspectos da vida humana. Quando a comunidade é danificada todos sofrem e quando é destruída, a sociedade declina e entra em colapso (ver os exemplos recentes da Argentina, do Equador e do
Iraque). Os dados analisados mostram que o senso de comunidade gerada pelas instituições convencionais da democracia é mínimo.

Os déficits democráticos criados pelo funcionamento deficiente das instituições convencionais da democracia representativa têm produzido orientações nos cidadãos de repúdio à forma como se pratica a política atualmente, levantando a necessidade de criar mecanismos societários de fiscalização dos gestores e instituições políticas.

Para efetivar tal fiscalização, as pessoas crescentemente se têm voltado para a participação em grupos informais à margem das organizações convencionais. Esse tipo de comportamento tem-se institucionalizado e funciona em caráter permanente. No entanto, a miopia dos governantes em reconhecer esses movimentos como parte de um novo contexto, em que essas organizações possam conviver cooperativamente com as instituições tradicionais, não tem possibilitado uma agenda que se oriente pela compreensão e pelo fortalecimento desses novos mecanismos de pressão. Nesse sentido, o capital social como instrumento de empowerment das pessoas para agirem coletivamente pode ser o mecanismo que estava faltando para gerar uma democracia mais eficiente e com qualidade, em que as demandas de grupos tradicionalmente excluídos não sejam esquecidas, ao mesmo tempo em que tais experiências fortaleçam o conceito de cidadania. Aceitar tal proposta, entretanto, envolve reconhecer que os paradigmas tradicionais que privilegiam soluções técnicas devem ser substituídos por outros que incorporem a dimensão subjetiva e social da democracia. Esse posicionamento implica a deconstrução do conhecimento estabelecido e a adoção de uma práxis mais conseqüente e propositiva da Ciência Política - o que, certamente, para grande parte da comunidade acadêmica, é uma heresia.

Marcello Baquero (baquero@orion.ufrgs.br) é Professor do Departamento de Ciência Política da Universidade Federal do Rio Grande do Sul (UFRGS) e Doutor em Ciência Política pela Florida State University (EUA). 


\section{REFERÊNCIAS BIBLIOGRÁFICAS}

ABRAMOVAY, M. \& CASTRO, M. G. 2003. Ensino médio : múltiplas vozes. Brasília : Organização das Nações Unidas para a Educação, a Cultura e a Ciência-Ministério da Educação.

ALMOND, G. A. \& VERBA, S. 1963. The Civic Culture. Princeton : University of Princeton Press.

AVRITZER, L. 2002. O orçamento participativo e a teoria democrática : um balanço crítico. In : AVRITZER, L. \& NAVARRO, Z. (orgs.). A inovação democrática no Brasil. São Paulo : Cortez.

BAKER, B. 1999. The Quality of Democracy in the Developing World: Why and How It Should Be Measured. The 27 $7^{\text {th }}$ European Consortium for Political Research, ECPR Joint Sessions, occurred at Mannheim (Germany), 26-31.Mar.

BANKSTON, C. L. \& ZHOV, M. 2002. Social Capital as a Process : The Meanings and Problems as a Theoretical Methapor. Sociological Inquiry. V. 72, n. 2, p. 285-317, Spring.

BAQUERO, M. \& PRÁ J. R. 1995. Matriz histórico-estrutural da cultura política no Rio Grande do Sul e padrões de participação política. Cadernos de Ciência Política. Série pré-edições. Universidade Federal do Rio Grande do Sul. Porto Alegre, N.3

BAQUERO, M. 2001. A vulnerabilidade dos partidos políticos e a crise da democracia na América Latina. Porto Alegre : UFRGS.

.2003. Uma auditoria cívica sobre a qualidade da democracia em Porto Alegre : um estudo propositivo. Relatório preparado para o Núcleo de Pesquisas sobre a América Latina. Porto Alegre : digit.

BARBER, R. B. 1999. Clansmen, consumers, and citizens: three takes on civil society. In: FULLWINDER, R. K. (ed.). Civil society, democracy, and civic renewal. Boston : Rowman and Littefield.

BRUSO, V., NAZARENO, M. \& STOKES, S. S. 2001. Clientelism and Democracy : An Analysis of Ecological Data from Argentina. Paper presented at the Annual Meeting of American Political Science Association, occurred at San Francisco, in September 2001.
CAMP, R. A. 2001. Democracy through Latin American Lenses. In : . (ed.). Citizen Views of Democracy in Latin America. Pittsburgh: University of Pittsburgh Press.

COOKE, P. \& MORGAN, K. 1998. The Associational Economy. Oxford: Oxford University Press.

COUTO, C. 1995. O desafio de ser governo : o PT na periferia de São Paulo. São Paulo: Brasiliense.

DAHL, R. 1971. Poliarchy. New Heaven: The Yale University Press.

DIAMOND, L. 1996. Is the Third Wave Over? Journal of Democracy, Baltimore, v. 7, n. 3, p. 20-37, July.

DAMATTA, R. 1993. Reflexões sobre o público e o privado no Brasil : um ponto de vista perverso. Caderno de Ciências Sociais, Belo Horizonte, v. 83, n. 3, p. 51-62, abr.

DURSTON, J. 2001. Capital social. Parte del problema, parte de la solución. Su papel en la persistencia y en la superación de la pobreza en América latina y el Caribe. Documento de Referencia. Santiago de Chile : Comisión Económica para América Latina y el Caribe.

EASTON, D. 1965. A Framework for Political Analysis. New Jersey : Prentice Hall.

EDWARDS, B. \& FOLEY, M. W. 1997. Escape from Politics? Social Theory and the Social Capital Debate. American Behavioral Scientist, n. 40, p. 550-561.

FACHIN, R. \& CHANLATN, A. (orgs.). 1998. Governo municipal na América Latina : inovações e perplexidades. Porto Alegre : UFRGS.

FERNANDES, F. 1968. Sociedade de classes e subdesenvolvimento. Rio de Janeiro : Zahar.

FINE, B. 1999. The Development State is Dead Long Live Social Capital? Development and Change, Oxford, v. 30, p. 1-19.

FUKUYAMA, F. 1995. Trust. The Social Virtues and the Creation of Prosperity. New York: The Free Press.

GAMARNIKOW, E. \& GREEN, A. 1999. Developing Social Capital : Dilemmas, Possibili- 
ties and Limitations in Education. In : HAYTO, M. (ed.). Tackling Disaffection and Social Exclusion. Londres : Kogan Page.

GARAY, J.L. 2001. Construcción de una nueva sociedad. Institute Internacional de Gobernabilidad. Buenos Aires. Colección de papers. Artigo n. 23, p.1-36. http://www.iigov.org. Acesso em : 24.abril.2002.

GENRO, T. 2001. Tarso diz que experiência do OP está esgotada.http://www.uol.com.br. Acesso em : 25.out.2001.

GUADILla, M. P. G. \& PEREZ, C. 2002. Democracy, Decentralization, and Clientelism. New Relationships and Old Practices. Latin American Perspectives, issue 126, v. 29, n. 5, p. $90-109$, Sept.

HIRST, P. 2002. Renewing Democracy through Associations. The Political Quarterly Publishing Company. Oxford (USA) : Blackwell.

HANIFAN, J. L. 1916. The Rural School Community Center. Annals of the American Academy of Political and Social Science, n. 67 , p. $130-138$.

HUNTINGTON, S. H. 1975. A ordem politica nas sociedades em mudança. Rio de Janeiro : Forense-Universitária.

IAZETTA, O. 2000. La reconstrución del Estado. Una mirada desde la democracia. Socialis. Revista Latinoamericana de Política Social. Rosario, Argentina, n. 2, mayo.

INGLEHART, R. 1988. The Renaissence of political culture. American Political Science Review, v. 82, n. 4, p. 1203-1230, Dec.

JOSLYN, M. R. \& LIGLER, A. 2001. Group Involvement and Democratic Orientations : Social Capital in the Post-Election Context. Social Science Quaterly, v. 82, n. 2, p. 357-368, Jun.

KARL, J. A., BANDUCCI, S. \& BOWLER, S. 2003. To Know It Is to Love It? Satisfaction with Democracy in the European Union. Comparative Political Studies, v. 36, n. 3, p. 271292, Apr.

KLIKSBERG, B. 2000. El rol del capital social y de la cultura en el proceso de desarrollo. In : KLIKSBERG, B. \& TOMASSINI, L. (comps.). Capital social y cultura : claves estratégicas para el desarrollo. Buenos Aires : Banco
Interamericano de Desarrollo.

KRISHNA, A. 2002. Enhancing Political Participation in Democracies: What is The role of Social Capital. Comparative Political Studies, v. 35 , n. 4, p. 437-460, May.

LECHNER, N. 1994.Os novos perfis da política - um esboço. In : BAQUERO, M. (org.). Cultura política e democracia. Os desafios das sociedades modernas. Porto Alegre : UFRGS.

1997. Tres formas de coordinación social. Revista de la CEPAL, Santiago de Chile, n. 61, 53-61, abr.

LAMOUNIER, B. \& SOUZA, A. 1991. Democracia e reforma constitucional no Brasil : uma cultura política em mudança. Dados, Rio de Janeiro, v. 34, n. 3, p. 311-347.

LUCAS, P. I. J. 2003. Universo político da juventude no início do século XXI. Caxias do Sul. Tese (Doutorado em Ciência Política). Universidade Federal do Rio Grande do Sul.

LYNE, M. M. 1997. The Voter's Dilemma, Factions, and Strange Bedfellows, or Why Latin American Political Parties Historically Weaken Democracy and How Can We Tell. Paper presented at the Latin American Studies Association LASA, Guadalajara, México.

MALONEY, W., SMITH, G. \& STOKER, G. 2000. Social Capital and Urban Governance : Adding a More Contextualized 'Top -Down' Perspective. Political Studies, v. 48, n. 4, p. 802-820.

MARGULIS, M. 1996. Globalización y cultura. Sociedad, Buenos Aires, n. 9, p. 5-17, Sept.

MELILLO, A. \& OJEDA, E. N. S. (comps.). 2002. Resiliencia. Descubriendo las próprias fortalezas. Buenos Aires : Paidos.

MISZTAL, B. A. 1998. Trust in Modern Societies. Malden : Blackwell.

MOISÉS, J. A. 1995. Os brasileiros e a democracia : bases sócio-políticas da legitimidade. São Paulo : Ática.

MOURA, S. 1998. Inovações municipais no Brasil recente. Impulsos de democratização e crise. In : FACHIN, R. \& CHANLATN, A. (orgs.). Governo municipal na América Latina : inovações e perplexidades. Porto Alegre: UFRGS.

NARAYAN, D. \& CASSIDY, M. F. 2001. A 
Dimensional Approach to Measuring Social Capital : Development and Validation of a Social Capital Inventory. Current Sociology, v. 49, n. 2, p. 59-102, Mar.

NEWTON, K. 2001. Trust, Social Capital, Civil Society, and Democracy. International Political Science Review, v. 22 , n. 2, p. 201-214.

NORRIS, P. 1999. Institutional Explanations for Political Support. In : (ed.). Critical Citizens : Global Support for Democratic Government. Oxford : Oxford University Press.

O'DONNELL, G. 1994. Delegative Democracy. Journal of Democracy, Baltimore, v. 5, n. 1, p. 55-69, Jan.

2000. Accountability horizontal : la institucionalización legal de la desconfianza política. PostData, Buenos Aires, p. 1-15, mayo.

OSTROM, E. 1994. Constituting Social Capital and Collective Action. Journal of Theoretical Politics, n. 6, p. 527-562.

PARAMIO, L. 1999. La democracia trás las reformas económicas em América Latina. Documento de Trabajo 99-03. Madrid : Instituto de Estudios Sociales Avançados.

PARGA, S. J. 2001. Transformaciones del conflicto, decline de los moviminentos sociales y teoria del desgobierno. Ecuador Debate, Quito, n. 53, p.19-39, ago.

PEREIRA, M. L. 1999. Negociação e parcerias : a gestão urbana democrático-participativa. São Paulo. Tese (Doutorado em Sociologia). Universidade de São Paulo.

PORTES, A. 1998. Social Capital : Its Origins and Applications in Modern Sociology. Annual Review of Sociology, v. 24, p. 1-24.

POWERS, N. R. 1999. Conceptualizing Democracy and Citizenship : Grassroots Insights for Comparative Method. Miami : digit.

PRZEWORSKI, A. 1999. Una mejor democracia, una mejor economia. Revista Etcétera, Ciudad de México, n. 222, p.1-12

PUTNAM, R. 1993. Making Democracy Work. Civic Traditions in Modern Italy. Princeton, NJ : Princeton University Press.

1995. Bowling Alone : America's Declining Social Capital. Journal of Democracy,
Baltimore, v. 6, n. 1, p. 65-78, Jan. 2000. Bowling Alone: The Collapse and Revival of American Community. New York : Simon and Schuster.

PUTNAM, R. \& GOSS, A. K. 2002. Introduction. In : PUTNAM, R. (ed.). Democracies in Flux. The Evolution of Social Capital in Contemporary Societies. New York : Oxford University Press.

RICCI, R. 2001. Do orçamento participativo à reforma do Estado. http:// www.notitia.rits.org.br/pub/newstorm. Acesso em : 29.jan.2001.

ROBTEUTSCHER, S. 2002. Advocate or Reflector? Associations and Political Culture. Political Studies, v. 50, p. 514-528.

ROSTOW, A. D. 1970. Transitions to Democracy. Toward a Dynamic Model. Comparative Politics, v. 2, n. 3. p. 337-363.

SEN, A. 1998. Teorias del desarrollo a principios del siglo XXI. In : EMMERIJ, L. \& ARCO NUÑEZ, J. (comps.). El desarrollo económico $y$ social en los umbrales del siglo XXI. Washington : Banco Interamericano de Desarrollo.

SMULOVITZ, C. \& PERUZZOTTI, E. 2000. Social Accountability in Latin America. Journal of Democracy, Baltimore, v. 11, n. 4, p. 147-158, Oct.

SOARES, J. A. \& PONTES, L. (orgs.). 1998. Desafios da gestão municipal democrática em Recife. Recife : Centro Josué de Castro de Estudos e Pesquisas-Instituto Polis.

SOARES, J. A. 1996. Mudanças e impasses na gestão das grandes cidades no Brasil, 19861996. Brasília. Tese (Doutorado em Sociologia). Universidade de Brasília.

STOLLE, D. \& ROCHON, 1998. T. R. Are All Associations Alike? American Behavioral Scientist, v. 42, n. 1, p. 47-65, Sept.

TOURAINE, A. 1997. De la mañana de los regímenes nacional-populares a la víspera de los movimientos sociales. Paper presented at the Latin American Studies Association LASA, Guadalajara, México, p. 1-18.

TRIGILIA, C. 2001. Social Capital and Local 
Development. European Journal of Social Theory, London, v. 4, n. 4, p. 427-442.

VALDÉZ, J. Culture and Development for Debate. Latin American Perspectives, issue 125, v. 29, n. 4, p. 31-46, July.

VERBA, S., SCHLOZMAN, K. L. \& BRADY, H.E. 1995. Voice and Equality. Civic Voluntarism in American Politics. Massachusetts: Harvard University Press.

WOLLEBAEK, D. \& SELLE, P. 2002. Does Participation in Voluntary Associations Contribute to Social Capital? The Impact of Intensity,
Scope, and Type. Non-profit and Voluntary Sector Quarterly, v. 31, n. 1, p. 32-61, Mar.

WOOLCOCK, M. 2001. The Place of Social Capital in Understanding Social and Economic Outcomes. ISUMA, v. 2, n. 1, p. 11-17, Spring.

YAMAGISHI, T. \& YAMAGISHI, M. 1994. Trust and Commitment in the United States and Japan. Motivation and Emotion, v. 18, n. 2, p. 129-166.

YOUNG, I. M. 2000. Inclusion and Democracy. New York : Oxford University Press.

\section{OUTRAS FONTES}

Revista do Terceiro Setor. 2003. Rio de Janeiro, em : jul.2003.

n. 879, jul. http://www.rits.org.br. Acesso 